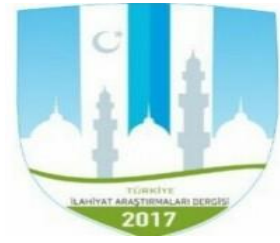

Türkiye Ilahiyat Araştırmalarn Dergisi

Turkey Journal of Theological Studies

[Tiad-2017]

[Tiad], 2021, 5 (2): 608-636.

\title{
Osmanlı Döneminde Sıradışı Bir Kazasker: Hüseyin Efendi ve Yapılan Temlikler
}

An Extraordinary Kazasker in the Ottoman Period: Hüseyin Efendi and the (Freehold Properties) Temliks

\section{Nevzat SAĞLAM}

Doç. Dr. Karabük Üniversitesi İslami İlimler Fakültesi, İslam Tarihi ve Sanatları/Assoc. Prof. Dr. Karabuk University, Faculty of Islamic Sciences nevzatsaglam@karabuk.edu.tr

Orcid ID: 0000-0003-0733-8939

Makale Bilgisi / Article Information

Makale Türü / Article Types : Araştırma Makalesi / Research Article

Geliş Tarihi / Received : : 13.10 .2021

Kabul Tarihi / Accepted $\quad: 26.12 .2021$

Yayın Tarihi / Published : : 27.12.2021

Yayın Sezonu : Aralı

Pub Date Season : December

Atıf/Cite as: Sağlam, Nevzat. "Osmanlı Döneminde Sıradışı Bir Kazasker: Hüseyin Efendi ve Yapılan Temlikler". Türkiye İlahiyat Araştırmaları Dergisi 5 / 2 (Aralık 2021): 608-636.

İntihal /Plagiarism: Bu makale, en az iki hakem tarafından incelenmiş ve intihal içermediği teyit edilmiştir. / This article has been reviewed by at least two referees and scanned via a plagiarism software. http://dergipark.gov.tr/tiad

Copyright $@$ P Published by Mustafa YİĞi̇TOĞLU- İstanbul- Turkey. All rights reserved..Since 2007 


\title{
Osmanlı Döneminde Sıra Dışı Bir Kazasker: Hüseyin Efendi ve Yapılan Temlikler
}

Öz

Osmanlı dönemi kazaskerleri arasında Hüseyin Efendi dikkat çekici bir şahsiyet olarak karşımıza çıkmaktadır. Onun Safranbolu'da başlayan hayatı, ilim tahsili için gittiği İstanbul'da farklı bir boyut kazanmıştır. Hekimlerin derdine deva bulamadıkları Sultan İbrahim'i okuduğu tesirli dualarla iyileştirmiş, bu sayede sultanın hocası konumuna yükselmiştir. Bundan sonra Cinci Hoca diye meşhur olan Hüseyin Efendi'nin siyasi nüfuzu artmış, kısa zamanda kazaskerlik makamına kadar çıkmıştır. Padişahın emriyle Safranbolu'da kendisine çok sayıda köy ve mezraa temlik edilmiştir. Büyük servet sahibi olan Hüseyin Efendi, annesi Hamide Hatun adına Safranbolu'da bir de vakıf kurmuştur. Ancak Sultan İbrahim'in tahttan indirilmesiyle hâmisini kaybetmiş, siyasi ve idari nüfuzu son bulmuştur. Bütün serveti elinden alındığ gibi sürgün edildiği Mihaliç'te idam edilmiştir. Bu çalışmada Kazasker Hüseyin Efendi, Safranbolu'da yaptırdığı eserler ve kendisine yapılan temlikler ele alınmıştır.

Anahtar Kelimeler: Kazasker, Kazasker Hüseyin Efendi, Cinci Hoca, Temlik, Safranbolu.

\section{An Extraordinary Kazasker in the Ottoman Period: Hüseyin Efendi and the (Freehold Properties) Temliks}

\begin{abstract}
Among the counties in the Ottoman period, Hüseyin Efendi is a trend-setter as a remarkable figure. His life, which started in Safranbolu, gained a different dimension in Istanbul, where he went to study. He healed Sultan İbrahim, for whom the physicians could not find a cure, with the effective prayers he recited, and in this way, he became the sultan's hodja. After that, the political influence of Hüseyin Efendi, who became famous as Cinci Hodja, increased, and he rose to the post of kazasker in a short time. By the order of the Sultan, many villages and hamlets were freehold property (temlik) to him in Safranbolu. Hüseyin Efendi, who had great wealth, also established a foundation in Safranbolu on behalf of his mother, Hamide Hatun. However, with the dethronement of Sultan İbrahim, he lost his protector and his political and administrative influence came to an end. He was executed in Mihaliç, where he was exiled as all his wealth was taken from him. In this study, the works that Kazasker Hüseyin Efendi had built in Safranbolu and the freehold property (temlik) made to him were discussed.
\end{abstract}

Keywords: Kadiasker, Kadiasker Hüseyin Efendi, Cinci Hodja, Temliks (Freehold Properties), Safranbolu.

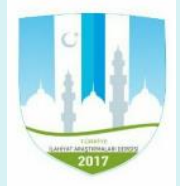




\section{Giriş}

Osmanlı kazaskerleri arasında Safranbolulu Hüseyin Efendi gerek bu makama yükselmesi gerek akıbeti açısından dikkat çekici bir şahsiyet olarak karşımıza çıkmaktadır. Zira onun kazaskerlik makamına gelişi, devlet hiyerarşisinde geçerli teâmüller dişında gerçekleşmiştir. Sultan İbrahim'in şehzadeliği döneminde yaşadığı öldürülme korkusunun ruh sağlığı ve psikolojisi üzerinde yarattığ rahatsızlıkları okuduğu tesirli dualarla iyileştirerek sultan nezdinde önemli bir mevki kazanmıştır. Kazandığı bu konumu sayesinde devlet içinde siyasi nüfuz ve büyük bir servete sahip olmuştur. Ancak Sultan İbrahim'in tahttan indirilmesiyle ikbal dönemi ve refah günleri sona ermiş siyasi nüfuzuyla bütün servetini sonunda da hayatını kaybetmiştir. Cinci Hüseyin Efendi'nin ilgi çekici hayatına başta kendi dönemindekiler olmak üzere bazı kaynaklarda yer verilmiştir. ${ }^{1}$

Diğer taraftan Cinci Hüseyin Efendi'nin hayatı son dönemde yapılan bazı çalışmalarda da ele alınmıştır. ${ }^{2}$ Ahmed Refik'in eserlerinde onun hayatı hikâye/roman tarzında anlatılmaktadır. ${ }^{3}$ Yapılan çalışmalarda Sultan İbrahim tarafından yapılan temlikler ele alınmamıştır. Osmanlı Arşivi'nde Bolu sancağının tımarları ile Taraklıborlu'da Kadıasker Hüseyin Efendi'ye temlik

1 Cinci Hüseyin Efendi hakkında bilgi veren kaynaklardan bazıları şunlardır: Naima Mustafa Efendi, Tarih-i Naîma (Ankara: Türk Tarih Kurumu, 2007); Evliya Çelebi, Evliya Çelebi Seyahatnâmesi (İstanbul: Yapı Kredi Yayınları, 1996); Kâtib Çelebi, Fezleke (İstanbul: Çamlıca Basım Yayın, 2016); Kara Çelebi-zâde Abdülaziz Efendi, Ravzatü'l-Ebrâr Zeyli (Tahlîl ve Metin) (Ankara: Türk Tarih Kurumu, 2003); Mehmed Süreyya, Sicill-i Osmânî (İstanbul: Sebil Yayınevi, 1996); Abdurrahman Abdi Paşa, Vekâyi nâme (İstanbul: Çamlıca Basım Yayın, 2008); Mehmed Halife, Târih-i Gılmânî (Ankara: Kültür ve Turizm Bakanlığı Yayınları, 1986).

2 Abdülkadir Özcan, "Hüseyin Efendi, Cinci Hoca”, Türkiye Diyanet Vakfı İslam Ansiklopedisi (İstanbul: Türkiye Diyanet Vakfı, 1998); Abdülkadir Özcan, “Safranbolu'da Üç Şahsiyet”, I. Ulusal Tarih İçinde Safranbolu Sempozyumu (4-6 Mayıs1999) (Ankara: Türk Tarih Kurumu, 2003); Hakkı Göktürk, "Cinci Akçesi, Cinci Parası", İstanbul Ansiklopedisi, ed. Reşad Ekrem Koçu (İstanbul: İstanbul Ansiklopedisi ve Neşriyat, 1965); Fatma Nur Güngör, Cinci Hoca (Hüseyin Efendi)'nin Safranbolu'daki Hayratı: Hamide Hatun Vakfı (Karabük: Karabük Üniversitesi, Yüksek Lisans, 2014); Tahsin Ünal, "Cinci Hoca ve Serveti Hakkında”, Resimli Tarih Mecmuası, (1955); M. Turhan Tan, Osmanl Rasputini Cinci Hoca (İstanbul: İnkılap ve Aka Kitabevleri, Tarihsiz); Abdulkerim Abdulkadiroğlu - Ülkü Özsoy, Safranbolu Meşhurları (Ankara: Anıl Matbaa ve Ciltevi, 2000); İsmail Katg1, “Osmanlı Devleti'nde Ulemâ Yozlaşmasının Tipik Bir Temsilcisi Olarak Safranbolu'lu Hüseyin Efendi: Nam-1 Diğer Cinci Hoca", Hikmet Yurdu 5/10 (Aralık 2012), 197235.

3 Ahmet Refik Altınay, Hoca Nüfûzu (İstanbul: Toplumsal Dönüşüm Yayınları, 1997); Ahmet Refik Altınay, Tarihî Sîmalar Tesâvîr-i Ricâl (İstanbul: Tarih Vakfı Yurt Yayınları, 2011); Ahmed Refik, Kadınlar Saltanatı (İstanbul: Orhaniye Matbaası, 1923); Ahmed Refik, Semmur Devri (İstanbul: Marifet Matbaası, 1927).

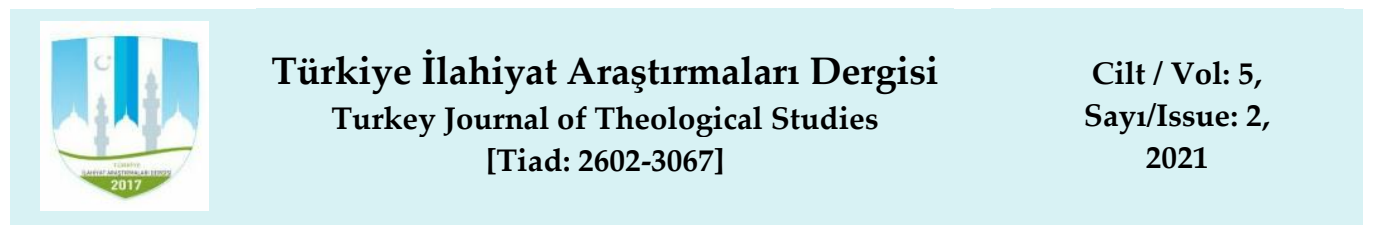


edilen arazileri gösteren bir mufassal tahrir defteri bulunmaktadır. Bu defterde temlik edilen köy ve mezraalar ayrıntılı olarak kaydedilmiştir. ${ }^{4} \mathrm{Bu}$ çalışmada Cinci Hüseyin Efendi'nin dikkat çeken yönlerine yer verilirken, aynı zamanda kendisine temlik edilen köy ve mezraalar, bunların sinırları ve gelirlerine de makalenin hacmi çerçevesinde yer verilmiştir.

\section{Hüseyin Efendi'nin Hayatı}

Hüseyin Efendi Safranbolu'da doğmuştur. ${ }^{5}$ Tam adı, Hüseyin b. Mehmed b. eşŞeyh Karabaş İbrahim Efendi'dir. Efsunculukla uğraştığı için Cinci Hoca olarak meşhur olan Hüseyin Efendi, aynı zamanda Kazasker Hüseyin Efendi olarak da anılmaktadır. Babası Mehmed Çelebi meşhur bir şeyh olarak bilinmektedir. İlk tahsilini babasından alan Hüseyin Efendi, ondan sihir ve efsunla ilgili bilgiler ve tesirli dualar öğrenmiştir. Soyu anne tarafından Sadreddin Konevî'ye kadar uzanmaktadır. 6 Dedesi Şeyh Karabaş İbrahim Efendi, Safranbolu'nun ileri gelenlerinden olup, vaizlik yapan salih bir zâttır. Karabaş İbrahim Efendi bir gün Safranbolu'da bir vaazında: "Hak Teâlâ'dan bir bela nâzil olacaktır. Biz feda oluruz, sâir Müslümanlara zarar olmaz" der. Bu konuşmadan sonra şeyhin evinde yangın çıar. Yangında Şeyh İbrahim beş evladıyla birlikte yanar. Yangından kurtulanlardan biri Hüseyin Efendi'nin babası Mehmed Çelebi ile Hacı Nurullah ve Emrullah Efendi isimli kadidır. ${ }^{7}$

Hüseyin Efendi ilim öğrenmek üzere annesiyle İstanbul'a gelmiş, Unkapanı'nın iç taraflarında Fil Yokuşu'nda Hâmid Efendi Medresesi'nde kalmıştır. Evliya Çelebi Ahfeş Efendi'den Molla Cami okurken, Cinci Hoca da Kitâb-ı İzzî̀yi okumuştur. ${ }^{8}$ Ayrıca Süleymaniye medresesinde Berber Biraderi Hasan Efendizâde Şeyh Mehmed Efendi'nin derslerine devam ederek onun hizmetinde bulunmuştur. Hocası Şeyh Mehmed Efendi'nin 1051/1641-1642'de İzmir'e kadı tayin edilmesi üzerine yalnız kalmış, sihir ve efsunculuğu geçim vasıtası haline getirmiş, bu sahada şöhret sahibi olmuştur. ${ }^{9}$ Ancak başta hocası olmak üzere ve

4 Osmanlı Arşivi (BOA) Tapu Tahrir Defteri [TT. d], No, 783. Sultan İbrahim'in tuğrasının yer aldığ 44 varak olan bu defterin vech-i meşruh üzere mahallinde yazıldığı belirtilmektedir.

5 Atatürk Kitaplığı Müteferrik Evrak, 60826. Cinci Hüseyin Efendi'nin Safranbolulu olmayıp, beşinci batından Sadreddin Konevi'nin torunu olduğu ve dededen babaya Konyalı olduğu, Karabaş-1 Veli İbrahim'in soyundan halen Karaman'da torunları bulunduğu ifade edilmektedir, bk. Ünal, "Cinci Hoca ve Serveti Hakkında”, 4163.

6 Naima Mustafa Efendi, Tarih-i Nâ̂ma (Ankara: Türk Tarih Kurumu, 2007), 3/973; Abdülkadir Özcan, "Safranbolu'da Üç Şahsiyet”, I. Ulusal Tarih İçinde Safranbolu Sempozyumu (4-6 Mayıs1999) (Ankara: Türk Tarih Kurumu, 2003), 117; Muhibbî, Hülâsatü'l-Eser (Beyrut, Tarihsiz), 2/122; Güngör, Cinci Hoca (Hüseyin Efendi)'nin Safranbolu'daki Hayratı: Hamide Hatun Vakfı, 18.

7 Tarih-i Naîma, 3/973-974.

8 Evliya Çelebi, Evliya Çelebi Seyahatnâmesi (İstanbul: Yapı Kredi Yayınları, 1996), 5/247; Kâtip Çelebi, Fezleke (İstanbul: Ceride-i Havadis Matbaası, 1287), 2/340.

9 Tarih-i Naîma, 3/974.İsmail Hâmi Danişmend, İzahlı Osmanlı Tarih Kronolojisi (İstanbul: Türkiye Yayınevi, 1972), 3/391; Özcan, “Hüseyin Efendi, Cinci Hoca”, 18/541. 
diğer müderrisler nazarında efsunculuğu sebebiyle itibarını kaybetmiştir. Hocası Şeyh Mehmed Çelebi kadı olarak İzmir'e tayin edildiğinde çevresindekiler Hüseyin Efendi'yi de beraberinde götürmesi hususunda 1srarda bulunduklarında kabul etmemiş: "Be hey efendi! Bizim ırzımız vardır. Avrat ve oğlana efsûn okuyan bir sehhâr-1 nâ-bekârı/büyücü, serseriyi bile götürüp mansıbımızda bed nam (kötü ün sahibi mi) mı olalım" diye cevap vermiştir. ${ }^{10}$ Israrlara rağmen hocası tarafından İzmir'e götürülmeyen Hüseyin Efendi, bir sene geçmeden efsunculuk sayesinde saraya girmiş, padişahın en yakınlarından biri olmuştur. ${ }^{11}$

\subsection{Saraya İntisab1}

Sultan IV. Murad'ın (1623-1640) ölümünden sonra tahta çıkan Sultan İbrahim (1640-1648), şehzadeliği döneminde kardeşlerinin öldürülmesine şahit olmanın ve sarayda devamlı cellat korkusuyla hapis hayatı yaşamaktan kaynaklanan, "hafakan ve sevdâvî illet"12 denilen hekimlerin çare bulamadıkları bir rahatsızlığa müptela olmuştur. Sultan İbrahim sadrazama yazdığı hatt-1 hümâyûnlarda sıkıntılarını şöyle dile getirerek derman istiyordu: "Sancı deyu yatırum, kâh arkama gelür, irkilür, kulaklarım tıkalur. ... şöyle sıkılmam vardır ki ölüyorum, gayetle halim yaman olmuştur, ... pek halim mükedder, mizacımda küdûrat vardır, ... göreyim seni bu benim derdime nice çare çalışursuz, ... beni seversen buna çare bulasın, ona buna sorasın,"13

Hüseyin Efendi'nin babasından öğrendiği efsun ve tesirli dualar ${ }^{14}$ ve hocası Şeyh Mehmed Çelebi'nin, "yanımda İzmir'e götürüp de kötü nâm sahibi mi olayım"15 diye götürmekten kaçındığı efsunculuğu, onu saraya taşıyarak padişahın yakını haline getirmiştir. ${ }^{16}$ Medrese arkadaşı Evliya Çelebi'nin

10 Tarih-i Naîma, 3/973-974; Ahmed Refik, Kadınlar Saltanatı (İstanbul: Orhaniye Matbaası, 1923), 20-21; "Cinci Hoca ve Serveti Hakkında", 4164; Ahmed Refik, Semmur Devri, 37-38. Hocas1 İzmir'den azledidikten sonra İstanbul'a döndüğünde Hüseyin Efendi'ye gelmiş, o da hocasına yakınlık göstermiştir, bk. Şem'dânizâde Fındıklı Süleyman Efendi, Mür'i't-Tevârîh (180B-345A) (İstanbul: İstanbul Üniversitesi, Yüksek Lisans, 2009), 137.

11 Atatürk Kitaplığı Müteferrik Evrak, 60826; Tarih-i Naîma, 3/973-974; Evliya Çelebi Seyahatnâmesi (İstanbul: Yapı Kredi Yayınları, 1999), 2. Kitap/247; Ziya Şakir, “Osmanlı Tarihinin Rasputini Cinci Hoca Hüseyin Efendi”, Resimli Tarih Mecmuası 2/24 (Aralık 1951), 1177-1179; Semmur Devri, 32-33.

12 Izahlı Osmanl Tarih Kronolojisi, 3/410; Semmur Devri, 32-33.

13 Tayyip Gökbilgin, “İbrahim”, İslam Ansiklopedisi (Ankara: Milli Eğitim Basımevi, 1967), 5/880881.

14 Tarih-i Naîma, 3/974.

15 Ahmet Refik Altınay, Hoca Nüfûzu, 61.

16 Tarih-i Naîma, 3/974.

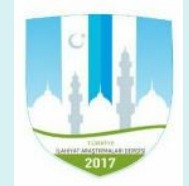


ifadesine göre, efsunculuk ve sihir konusundaki şöhreti saraya kadar ulaşan Hüseyin Efendi okuduğu tesirli dualarla çaresizlik içindeki Sultan İbrahim'i iyileştirmiş, onun hocası olmuş, bundan sonra istikbali parlamıştır. ${ }^{17}$ Annesi Hâmide Hatun'un haremden birine oğlunun tesirli duâlarla ruhi hastalıklara mübtela olanları iyileştirdiğini, padişahı da iyileştirebileceğini söylemesi üzerine Cinci Hüseyin Efendi Mahpeyker Kösem Vâlide Sultan tarafından saraya çağırılmıştır. Gerçekten de padişahı okuduğu tesirli dualarla ruhi sıkıntılardan kurtararak rahatlatmış, hatta çocuk sahibi olmasını sağlamıştır. Bunun karşlığında sultanın maddi ve manevi birçok lütuf ve ihsanlarına nail olmuştur. Devlet ricali arasında önemli mevki ve makamlara çıkmıştır. Böylece şöhreti daha da artan ve Cinci Hoca diye meşhur olan Hüseyin Efendi sarayda padişah nezdinde en etkili kişilerinden biri olmuş, Mahmud Paşa Camii yakınında kendisine dayalı döşeli bir konak/saray tahsis edilmiştir. ${ }^{18}$

Medrese tahsilini bile tamamlamamış olan Cinci Hüseyin Efendi, Padişah nezdindeki nüfuzunu kullanarak devletin önemli makamlarını birer birer elde etmeye, mal ve servet biriktirmeye başlamıştır. Sultan İbrahim'in emriyle, Şeyhülislam Zekeriyya-zâde Yahya Efendi'nin: "Kânun değildir" diye karşı çıkmasına rağmen 1052/1642'de Sahn-1 Semân ve Süleymaniye Medresesi müderrisliğine tayin edilmiştir. ${ }^{19}$ Ulemâ daha bu pâyelerin verilmesini bile hazmedememişken, İstanbul Kadılığı pâyesi verilerek 1052/1643'te Galata kadısı, 1054/1644'te Rumeli pâyesiyle de Anadolu kazaskeri ve padişah hocası (hoca-i sultânî) yapılmıştır. Padişahın emriyle, Anadolu kazaskerliğinden

17 Atatürk Kitaplığı Müteferrik Evrak, 60826; Tarih-i Naîma, 3/973-974; Evliya Çelebi Seyahatnâmesi (İstanbul: Yapı Kredi Yayınları, 1999), 2. Kitap/247; Ziya Şakir, “Osmanlı Tarihinin Rasputini Cinci Hoca Hüseyin Efendi”, Resimli Tarih Mecmuası 2/24 (Aralık 1951), 1177-1179; Semmur Devri, 32-33. Adı geçen eserde Sultan İbrahim'in tahta çıkışı ve Hüseyin Efendi'inin (Cinci Hoca'nın) saraya intisabı hikâye üslûbuyla anlatılmaktadır.

18 Şeyhi Mehmed Efendi, Şekāik-ı Numaniye ve Zeyilleri Vekâyiu'l-Fudalâ, (İstanbul: Çağrı yayınları, 1989), 1/178-179; Evliya Çelebi Seyahatnâmesi, 2. Kitap/247; Tarih-i Naîma, 3/973-974; Fezleke, 2/340341; Muhibbî, Hülâsatü'l-Eser, 2/122-123; Müri't-Tevârîh (180B-345A), 141-142; İzahlı Osmanlı Tarih Kronolojisi, 3/391; “Osmanlı Tarihinin Rasputini Cinci Hoca Hüseyin Efendi”, 1178; Ahmet Refik Altınay, Tarihî Sîmalar Tesâvîr-i Ricâl (İstanbul: Tarih Vakfı Yurt Yayınları, 2011), 63.; Kadınlar Saltanatı, 22,32; Mehmet Nermi Haskan, Yüzyıllar Boyunca Üsküdar (İstanbul: Üsküdar Belediyesi, 2001), 1340-1341; Özcan, "Safranbolu'da Üç Şahsiyet”, 117. Ali Fuat Bilkan, Fakihler ve Sofuların Kavgası (İstanbul: İletişim Yayınları, 2016), 39; "Hüseyin Efendi, Cinci Hoca”, 18/542. Hüseyin Efendi'nin Safranbolu'dan Osmanlı sarayına uzanan ve idamla sonuçlanan hayatı hikâye tarzında kaleme alınmıştır, bk. Semmur Devri, 39. Ahmed Reşid Cinci Hoca'ya büyük bir saray yaptırıldığını, tefrişi için iki milyon akçe verildiğini belirtmektedir, bk. Ahmed Reşid, Haritalı ve Resimli Mükemmel Tarih-i Osmanî (İstanbul: Artin Asaduryan ve Mahdumları Matbaas1, 1327), 135; Kâmil Paşa, Târih-i Siyâsi Devlet-i Aliyye-i Osmâniyye (İstanbul: Ahmed İhsan Matbaası, 1327), $2 / 82$.

19 Atatürk Kitaplığı Müteferrik Evrak, 60826. Padişahların daima iltifatını gören Yahya Efendi'nin, önemsiz ve değersiz olmayı kabullenemediği için sıkıntı ve kederinden yatağa düşmüş ve ölmüştür, bk. Tarih-i Naîma, 3/991. 
mazul Karaçelebi-zâde Mahmud Efendi'nin kızıyla evlenmiştir. Kazaskerlikten 1056/1646'da azledilmiş aynı yıl tekrar tayin edilmiştir. Azledildiği 12 Receb 1057/13 Ağustos 1647 tarihine kadar iki defa daha aynı görevden alınmış, tekrar iade edilmiştir. ${ }^{20}$ Padişah'ın yanından ayrılmayan Cinci Hoca'nın sultana yakınlığı sadrazam ve Vâlide Sultan'dan daha ileri dereceye varmış, Edirne'ye giden padişaha Cinci Hüseyin Efendi arkadaşlık etmiştir. ${ }^{21}$ İlmi yeterliliği ve devlet tecrübesi olmadığı halde tayin ve görevden almada padişaha yakınlığını kullanarak şeyhülislamın yetkisine de müdahalede bulunmuştur. Medrese eğitimini dahi tamamlamamış birinin hak etmediği ilmi mertebe ve mansıplara yükselmesi (hiyerarşi/silsile-i merâtibin ayaklar altına alınması) ulemâ arasında rahatsızlık meydana getirmiştir. ${ }^{22}$

Dönemin veziriazamı Kemankeş Kara Mustafa Paşa'nın devlet gelirlerini artırmaya, masraflarını azaltmaya yönelik askeri, idari ve ekonomik alanda birtakım düzenlemelere kalkışması saray halkı ve nüfûzlu kişilerine menfaatlerine dokunduğundan epeyce düşman kazanmıştı. Başta Vâlide Kösem Sultan olmak üzere Silahtar Yusuf Paşa ve Cinci Hoca bunlar arasında yer alıyordu. ${ }^{23}$ Cinci Hoca ikbalinin önünde engel olarak gördüğü Vezîriazam

20 Osmanlı Arşivi (BOA), Topkapı Sarayı Müzesi Arşivi Evrakı [TSMA. E], No,794, 29; Şeyhi Mehmed Efendi, Şekāik-ı Numaniye ve Zeyilleri Vekâyiu'l-Fudalâ, 1/179. Atatürk Kitaplı̆̆1 Müteferrik Evrak, 60826; Fezleke, 2/340-341; Muhibbî, Hülâsatü'l-Eser, 2/122-123; Müri't-Tevârîh (180B-345A), 137; Mehmed Süreyya, Sicill-i Osmân̂̀ (İstanbul: Sebil Yayınevi, 1996), 2/208; Semmur Devri, 38; Hulusi Yazıcıoğlu, Küçük Osmanlı'nın Öyküsü Safranbolu (İstanbul: Şa-to Türkiyat, 2001), 93; Abdulkadiroğlu - Özsoy, Safranbolu Meşhurları, 88-89.

21 Solakzâde Mehmed Hemdemî Çelebi, Solak-zâde Tarihi (Ankara: Kültür Bakanlığı Yayınları, 1989), 2/562; Ahmed Reşid, Haritalı ve Resimli Mükemmel Tarih-i Osmanî, 135.Kâmil Paşa, Târih-i Siyâsi Devlet-i Aliyye-i Osmâniyye, 2/81-82.

22 Evliya Çelebi Seyahatnâmesi, 2. Kitap/247; Naîmâ Mustafa, Tarih-i Naîma, 3/973; Kadınlar Saltanatı, 22; Yazıcıoğlu, Kü̧̈ük Osmanlı'nın Öyküsü Safranbolu, 93. Caroline Finkel, Rüyadan İmparatorluğa Osmanlı İmparatorluğu'nun Öyküsü 1300-1923, çev. Zülal Kılıç (İstanbul: Timaş Yayınları, 2007), 203. Seyfettin Ünlü, "Yeniçeriler", Osmanl Ansiklopedisi (İstanbul: Ağaç Yayıncılık, 1997), 4/88; Ahmet Refik Altınay, Hoca Nüfûzu (İstanbul: Toplumsal Dönüşüm Yayınları, 1997), 62; Muammer Aksoy, Aytekin Kuş, Müze Kent Safranbolu (Ankara: Safranbolu Hizmet Birliği Kültür Yayını, 1996), 14; Bilkan, Fakihler ve Sofuların Kavgası, 40.

23 Tarih-i Naîma, 3/977; Johann Wilhelm Zinkeisen, çev. Nilüfer Epçeli, Osmanlı Imparatorluğu Tarihi (İstanbul: Yeditepe Yayınevi, 2011), 4/373; Solak-zâde Tarihi, 2/559-560; Târih-i Siyâsi Devleti Aliyye-i Osmâniyye, 2/ 81; Müri't-Tevârîh (180B-345A), 135; Gökbilgin, “İbrahim”, 5/880.; Feridun Emecen, "İbrâhim", Türkiye Diyanet Vakfi İslam Ansiklopedisi (İstanbul: Türkiye Diyanet Vakfı, 2000), 21/274-281.

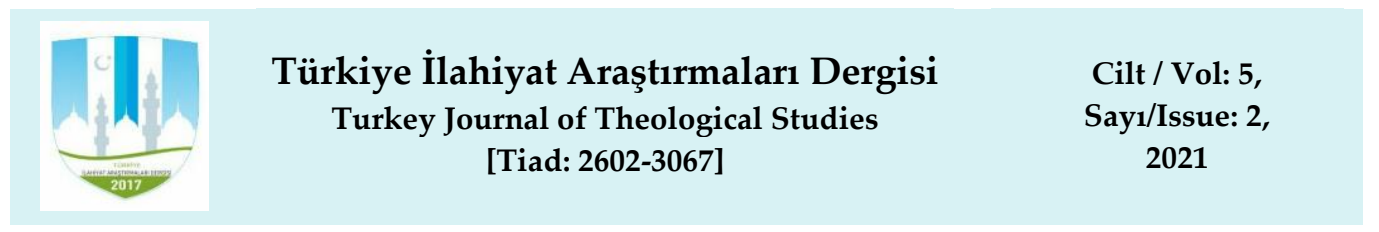


Kemankeş Kara Mustafa Paşa'yı saraydaki nüfûzunu kullanarak 1053/1644'te katlettirdikten sonra Anadolu Kazaskerliği'ne getirilmiştir. ${ }^{24}$

Diğer taraftan mal ve servet biriktirme hirsıyla hareket eden Cinci Hüseyin Hoca, kadılıkları ve devlet görevlerini rüşvet karşılığında dağıtmaya başlamıştır. Mekke kadılığına Fetva Emini Mehmed Çelebi beş bin kuruş vererek atanmıştır. ${ }^{25}$ Tavil Ahmed Ankara nâibliğine dört bin kuruş, Kadı İsmail de Kayseri kadılığına üç bin kuruş karşılığında tayin olunmuştur. Mülakkab Muslihuddin Şam kadılığına on dokuz bin kuruşa, Siyami Efendi Selanik kadılığına on bin kuruşa sahip olmuştur. Arpalık kavgası ve mansıp alış-verişi işleri, rezalet boyutuna çıkmıştır. Hüseyin Efendi'nin yaptığ suistimaller padişahın kulağına kadar gitmiş, nefretini kazandırmıştır. ${ }^{26}$ Vüzera, vükela gibi ileri gelen devlet görevlilerinin rüşvete bulaşmaları bir yana, devlet bütçesine konulması ve Girit'te savaşan orduya gönderilmesi gereken paralar, padişahın etrafındaki birkaç kişiye ihsan olarak verilir hale gelmiştir. ${ }^{27}$ Devletin idari ve ekonomik istikrarı sarsılmış, Sultan İbrahim'in sekiz yıl süren saltanatında dört şeyhülislam değişmiştir. Safranbolu'dan İstanbul'a geldiğinde duası ve nefesinden başka bir şeyi olmayan, büyücülük ve efsunculukla meşhur olan Hüseyin Molla kısa zamanda Kazasker Hüseyin Efendi olmuştur. ${ }^{28}$

Kazasker Hüseyin Efendi'nin iki seneyi aşkın devam eden ikbal günlerine nazar değmiş, mal biriktirme hırsıyla görevini kötüye kullandığı ve rüşvet aldığına dair söylentilerin ayyuka çıkması ve padişahın kulağına kadar gitmesi üzerine gözden düşmüş, 1647'de muhteşem sarayından çıkarılmıştır. Söz konusu saray daha sonra padişahın kız kardeşi Cevher/Gevher Sultan'a tahsis edilmiştir. ${ }^{29}$ Bundan sonra hocanın bütün düzeni bozulmuş, aynı yıl içinde önce İznik'e, burada sekiz gün kalıp İstanbul'a döndükten birkaç gün sonra da Gelibolu'ya sürgün edilmiştir. ${ }^{30}$ On gün sonra İstanbul'a dönmüşse de umduğu iltifatı

24 Atatürk Kitaplı̆̆1 Müteferrik Evrak, 60826; Târîh-i Naîmâ, 3/1000, 1069; Fezleke, 2/ 341; Şemseddin Sami, Kâmusu'l-A lâm (İstanbul: Mihran Matbaası, 1308), 3/1840; Danışmend, İzahlı Osmanlı Tarih Kronolojisi, 3/392; Aksoy, Kuş Aytekin, Müze Kent Safranbolu, 14.; Nazım Tektaş, Osmanlı 2 (Saraydan Sürgüne) (İstanbul: Burak Yayınları, 1999), 464; Emecen, “İbrâhim”, 21/274281.

25 Ancak bindiği gemi korsanlar tarafından basıldığı ve esir düştüğü için görev yerine gidememiştir, bk. Tarih-i Naîma, 3/1012.

26 Tarih-i Naîma, 3/1095-1096, 1173; Târih-i Siyâsi Devlet-i Aliyye-i Osmâniyye, 2/87; Ahmet Refik Altınay, Hoca Nüfûzu, 64-69. Semmur Devri, 34-42.

27 Evliya Çelebi Seyahatnâmesi, 2. Kitap/247; Târih-i Siyâsi Devlet-i Aliyye-i Osmâniyye, 81.

28 Ahmet Refik Altınay, Hoca Nüfûzu, 60-61.

29 Târîh-i Naîmâ, 3/1096; Ahmed Refik, Kadınlar Saltanatı, 144.; Joseph Freiherr von Hammer Purgstall, Büyük Osmanlı Tarihi, çev. Mümin Çevik - Erol Kılıç (İstanbul: Üçdal Neşriyat, 1990), $5 / 396$.

30 Şekāik-ı Numaniye ve Zeyilleri Vekâyiu'l-Fudalâ, 1/179; Fezleke, 2/341; Mehmed Süreyya, Sicill-i Osmânî (İstanbul: Sebil Yayınevi, 1996), 2/209; Târih-i Siyâsi Devlet-i Aliyye-i Osmâniyye, 2/ 87.

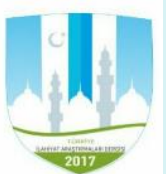

Türkiye İlahiyat Araştırmaları Dergisi 
göremediği gibi Sultan İbrahim'in tahttan indirilerek 1058/1648'de öldürülmesiyle de hâmisini kaybetmiş oldu. Cinci Hüseyin Efendi'ye öteden beri kin ve düşmanlık besleyenlerin eline önemli bir fırsat geçmiş oldu. Sultan IV. Mehmed'in tahta çıkması Cinci Hoca için sıkıntılı günlerin başlaması anlamına geliyordu. Mazul Kazasker Hüseyin Efendi bundan sonra birçok zorluklarla yüz yüze gelmeye başladı. İkbal günlerinden (1053-1057/1643-1647) sonra sahip olduğu mevki ve makamını kaybetti. Bir ay kadar sadrazam Sofu Mehmed Paşa'nın sarayında hapsedildi. ${ }^{31}$

\subsection{Serveti ve Âkıbeti}

Cinci Hüseyin Efendi Sultan İbrahim zamanında, işini gördürmek isteyen ve şerrinden korkan halktan ve ulemadan aldığı hediyeler ve rüşvetlerle kısa zamanda çok mal biriktirmiştir. ${ }^{32}$ Kazaskerliği döneminde bedelsiz ve rüşvetsiz vermediği devlete ait makamlar ve tevcihlerden aldığı paralarla servetini artırmış, İstanbul'da bina ettiği sarayın muhtelif yerlerine saklamıştır. ${ }^{33}$ Kethüdâsı Hacı Nurullah bile iki sene önce çarşıda müflis birisi iken onun sayesinde o da servet sahibi olmuştur. ${ }^{34}$ Sultan İbrahim'in katledilmesinden sonra oğlu IV. Mehmed (1648-1687) tahta çıkmıştır. Tahta çıkan yeni padişahın askere vereceği cülûs bahşişi için hazinede para kalmadığından Cinci Hoca'dan iki yüz kese akçe yardımda bulunması istenmiştir. Evliya Çelebi, Sultan İbrahim'in hazineyi Cinci Hoca, Şekerpâre, Telli Haseki gibi kişilerle birçok musahiplere harcadığını belirtmektedir. Çünkü bunların padişahın yanından bir an bile ayrılmadıklarını hatta padişaha sadrazam ve validesinden daha yakın olduklarını ve bu sayede kendilerine büyük gelirler tahsis edildiğini ifade etmektedir. ${ }^{35}$ Hüseyin Efendi kendisinden iki yüz kese akçe isteyen vezîriazama, beni yeni padişaha hoca yaparlarsa yüz kese akçe vereceğim diye

31 Şekaik-ı Numaniye ve Zeyilleri Vekâyiu'l-Fudalâ, 1/179; Solakzâde Tarihi, 2/568; Abdurrahman Abdi Paşa, Vekâyinâme (İstanbul: Çamlıca Basım Yayın, 2008), 10; Ahmet Refik Altınay, Tarihî Sîmalar Tesâvîr-i Ricâl, 66-67.

32 Cinci Hoca'nın nasıl büyük bir servete sahip olduğuna dair Târih-i Nâ̂mâ'da Nakîbüleşrâf Zeyrek-zâde Abdurrahman Efendi'den naklen şu hadise anlatılmaktadır: Bağdad kadılığından azledilmiş İstanbul'a dönüyordum. Bağdad valiliğinden azledilmiş olan Hüseyin Paşa da İstanbul'a gidiyordu. Diyarbekir'de karşılaştık. Hüseyin Paşa'nın hizmetçileri bir beygirden ağır bir heybe indirdiler. Paşa da onlara yardım etti. Heybeye özel bir ihtimam gösteren Paşa heybeyi yanına alıp üzerini örttü. Paşaya: "Heybede ne var ki bu kadar ihtimam gösteriyorsunuz" dedim. Hüseyin Paşa: “Behey Efendi! İstanbul'da Cinci Hoca dedikleri muzır, tamahkarın şerrinden kurtulmak için hazırladığım beş bin kırmız filori var" dedi, bk. Târîh-i Nâ̂mâ, 3/1173; Göktürk, "Cinci Akçesi, Cinci Parası", 7/3579.

33 Târîh-i Naîmâ, 3/1173, 1175; Fezleke, 2/341.

34 Târîh-i Naîmâ, 3/1173.

35 Evliya Çelebi, Evliya Çelebi Seyahatnâmesi, 5/30; Evliya Çelebi Seyahatnâmesi, 2. Kitap/ 247.

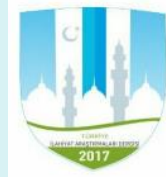


haber göndermiştir. Fakat onun gerçek niyetinin bozgunculuk olduğu, bu talep ve teklifinin kanunsuz işler yapmak için yeni bir fırsat arayışı olarak değerlendirilmiştir.

Veziriazamın cülûs bahşişi için istediği 200 kese akçeyi parası olduğu halde vermek istemeyince Sadrazam Sofu Mehmed Paşa'nın ${ }^{36}$ emriyle Çavuşbaşı Abdülfettah Ağa tarafından evi basılmıştır. Kayınpederi Mahmud Efendi Cinci Hüseyin Efendi'ye nasihatte bulunarak, Süleymaniye vakfından haksız olarak aldığı vazifeyi ve istenen parayı vermesini tavsiye ettiyse de Hüseyin Efendi: "Ben mertlikle adam oldum. Canım tende iken onlara bir akçe vermem" diye cevap vermiştir. Kethüdâsı Hacı Nurullah'ın, bu kadar parayı sana yedirmezler, hiç olmazsa kırk elli kese akçe vermesini tavsiye etmesi üzerine; getir şu keseleri ayarı düşük, eksik ve silik kuruşları, kırık altınları ayırıp bir miktar akçe verelim demiştir. Ayarı düşük paraları seçmekle meşgul iken Çavuşbaşı Abdülfettah Ağa tarafından evi basılınca kaçarak bir odada hasırın altına saklanmıştır. Saklandığı yerde hocayı yakalayan çavuşbaşı kinâyeli bir şekilde: “Efendi, önceden yüce ruhları çağırırdı. Şimdi süfli/cinleri çağırmak için hasırın altına girmiş" diyerek hocanın efsunculuğuna göndermede bulunmuştur. Hüseyin Efendi de çavuşbaşına ve yanındakilere: “Bire asılacaklar! Ben kazasker ve ulema değil miyim? Çekin elinizi bire habisler! diye çıkışmış, çavuşbaşı ise konuşturmayın şunu alın götürün diye emir verince sille tokat yakalandığı yerden yaka-paça sadrazamın huzuruna getirilmiştir. Sadrazam tekrar cülûs bahşişi için iki yüz kese akçe yardımda bulunmasını isteyince: "Ben parayı saraya ve kitaba verdim. Paramın tamamı elli kese akçe yoktur" diye parasını inkâr etmiştir. Sadrazamın bütün ısrarlarına rağmen yemin ederek, vermemekte direnmiştir. Bu arada kayınpederi Mahmud Efendi'nin kethüdası üstünü başını düzeltirken: "Hey Efendi! Allah yardımcın olsun. Tamahkarlığın ve hırsın seni bu hale getirdi. Sonun nasıl olacak? Söz tutmadın, biz ne yapalım" deyince, Hüseyin Efendi: "Behey çelebi! Benim suçum nedir? Bana Allah'ın verdiği malı bu zâlimlere göz göre göre verip fakir mi kalayım? Emir şerîatindir" diye karşıllı vererek istenen parayı yine vermemekte ssrar edince, kethüdası Hacı Nurullah ile birlikte hapsedilerek işkence ve eziyete maruz kalmıştır. ${ }^{37}$ Evinde yapılan aramada bohçalarla hediyeler, iki sandık dolusu altın ve mücevher ile elliden fazla samur kürk bulunmuş ve hepsine el konularak Paşa Kapısı'na taşınmıştır. Hüseyin Efendi

\footnotetext{
36 Sadrazam Ahmed Paşa'nın yerine ulemâ, bürokrat ve ocak ağaları tarafından vezîriâzam yapılan Sofu Mehmed Paşa da bir yıl dolmadan vezîriâzamlıktan azledildi. Malları müsadere edildi, arkasından Malkara'ya sürgüne gönderildi. Sekseni aşkın yaşına rağmen 1059/1649'da Malkara'da idam edildi, bk. Davut Erkan, "Sofu Mehmed Paşa", Türkiye Diyanet Vakfi İslâm Ansiklopedisi (İstanbul: Diyanet Vakf1, 2016), Ek-2/521-523.

37 Târîh-i Naîmâ, 3/1174-1175; Tarihî Sîmalar Tesâvîr-i Ricâl, 68-69.
}

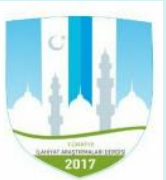

Türkiye İlahiyat Araştırmaları Dergisi 
cehaletinden ve akılsızlığı yüzünden biriktirdiği binlerce keselik malın kendisine kalacağını zannederek yanılmıştır. ${ }^{38}$

Kazaskerliği döneminde yazdığı rûznâmeler getirtilerek kadılık, müderrislik gibi makamlara bizzat kendi yaptığı atamalardan ve padişahın yanındaki nüfuzunu kullanarak yaptırdığı tevcihlerden aldığ miktarının üç bin keseyi aşkın olduğu tespit edilerek zorla tahsili kararlaştırılmıştır. Paralarını ve mallarını nereye sakladığını söyletmek için Cellat Kara Ali, Cinci Hoca'nın hapsedildiği yere gönderilmiştir. Cellat Kara Ali'nin gönderilmesi üzerine işin ciddiyetini kavrayıp, işkence korkusuyla hem kendisi hem kethüdası Hacı Nurullah duvarlara, merdiven altlarına ve toprağa sakladıkları paraların ve altınların yerini söylemek zorunda kalmışlardır. ${ }^{39}$ Söyledikleri yerlerde ve evinde yapılan kazılarda on iki gügüum çil akçesi ve eski-yeni 70 bin kuruşu olduğu anlaşılmıştır. Evdeki şahsi eşyalarına ve diğer emvaline dokunulmamıştır. Veziriazam, Cinci Hoca'nın kayınpederi Mahmud Efendi'ye de kızının mehr-i müecceli olarak bin altın göndermiştir. ${ }^{40}$ Cinci Hoca'nın ele geçirilen ve IV. Mehmed'in cülûs bahşişi olarak dağıtılan bu paralara halk arasında Cinci akçesi denilmiştir. Cinci Hoca sanki IV. Mehmed'in cülûs bahşişi için para biriktirmiş oldu. Zira cülûs bahşişinin neredeyse tamamına yakını onun parasıyla ödenmiştir. Cülûs bahşişi olarak dağıtılan 1.958.400 duka altının 1.920.000'nin Cinci Hoca'nın parası olduğu belirtilmektedir. ${ }^{41} \mathrm{Bu}$ kadar serveti birkaç sene içinde devlet ricalinden aldığ rüşvetler ve haksız yollarla elde ettiği iddia edilmektedir. ${ }^{42}$

Öte yandan sahip olduğu altın ve gümüş kap kacağının değerinin yaklaşık 200 kese akçe olduğu ifade edilmektedir. Bunlarla birlikte bütün kıymetli eşyaları müsadere edilmiştir. Kazaskerliği zamanında Süleymaniye vakfından haksız olarak almakta oldukları kendisi için günlük 500, kethüdası Hacı Nurullah için

38 Şekaik-ı Numaniye ve Zeyilleri Vekâyiu'l-Fudalâ, 1/179; Fezleke, 2/ 341; Târîh-i Naîmâ, 3/1175-1176. 39 Târîh-i Naîmâ, 3/1176, 1096; Ahmed Refik, Kadınlar Saltanatı, 144.; Joseph Freiherr von Hammer Purgstall, Büyük Osmanlı Tarihi, 5/438.

40 Târîh-i Naîmâ, 3/1176-1177; Evliya Çelebi Seyahatnâmesi, 2. Kitap/ 248; Muhibbî, Hülâsatü'l-Eser, 2/ 123; İ. Hakkı Uzunçarşılı, Osmanlı Tarihi (Ankara: Türk Tarih Kurumu, 1988), 3/241; Nazım Tektaş, Osmanlı 2 (Saraydan Sürgüne), 478; Küçük Osmanlı'nın Öyküsü Safranbolu, 93; Ünal, “Cinci Hoca ve Serveti Hakkında”, 4165-4166.; Göktürk, “Cinci Akçesi, Cinci Parası”, 7/3579.

41 İahlı Osmanlı Tarih Kronolojisi, 3/413-414; Robert Mantran, 17. Yüzyılın İkinci Yarısında İstanbul, çev. M. Ali K1lıçbay, Enver Özcan (Ankara: Türk Tarih Kurumu, 1990), 1/234.; Johann Wilhelm Zinkeisen, Osmanl Imparatorluğu Tarihi, 4/563.; Güngör, Cinci Hoca (Hüseyin Efendi)'nin Safranbolu'daki Hayrat: Hamide Hatun Vakfi, 20.

42 Târîh-i Naîmâ, 3/1178; Mustafa Nuri Paşa, Netâyicü'l-Vukū'ât (Ankara: Birleşik Yayınevi, 2008), 289; Ziya Şakir, “Osmanlı Tarihinin Rasputini Cinci Hoca Hüseyin Efendi”, 1179.

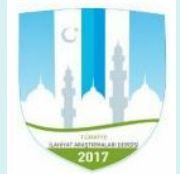


200 akçenin geriye dönük hesabı yapılarak 15 bin akçe vakfa iade edilmiştir. Ayrıca Sultan İbrahim döneminde Safranbolu ve Bolu sancağında kendisine temlik ettirdiği köy ve mezraaların ${ }^{43}$ mülknâmeleri de elinden alınmıştır. ${ }^{44}$

Kethüdası Hacı Nurullah'ın da yüz elli kese akçesi alınarak serbest bırakılmıştır. Cinci Hüseyin Efendi ise bir süre hapiste kaldıktan sonra İbrim Mirlivâsı olarak Mısır'a sürgün edilmiştir. ${ }^{45}$ Kumkapı'dan bir kayıkla yola çıkmıştır. Karacabey'e/Mihaliç'e geldiğinde yakalandığı nikris hastalığı yolculuğa devamına imkân vermeyince han seçilmesinde etkisi olduğ ${ }^{46}$ Kırım Han'ı III. İslam Giray'ın (1644-1654) tavassutuyla Mihaliç'te kalmıştır. ${ }^{47}$ Ancak Cinci Hoca biriktirdiği bunca servetine el konulmasını hazmedememiş, mallarına haksız yere el konulduğu yolundaki söylentiler, şüphe uyandıran hareketler ve taraftarlarının kargaşaya sebebiyet vereceğine dair bir takım dedikodular yüzünden ve Kırım hanının şefaatiyle İstanbul'a döner, problem çıkarır endişesiyle hakkında idam kararı verilmiştir. İdam kararını icra etmek üzere gönderilen Limnili Hüseyin Çavuş'a: "Nedir Çavuş, müjde ile mi geldin," sorusuna karşılık çavuşun idam fermanını eline vermesi üzerine müsaade isteyerek, abdest alıp namaz kıldıktan sonra Şevval 1058/Ekim-Kasım 1648'de katledilmiştir. ${ }^{48}$ Esasen Sultan İbrahim'in son zamanlarında Sofu Mehmed Paşa'yı veziriazam tayin ettiren isyancıların önde gelenleri tarafından daha önce katledilecek iken, kayınpederi Mahmud Efendi'nin gayretiyle kılık/elbisesini değiştirerek canını kurtarmış, fakat hakkında takarrür eden

43 Osmanlı Arşivi (BOA), Tapu Tahrir Defteri [TT. d], No. 783; Ömer Lütfi Barkan, Türkiye'de Toprak Meselesi Toplu Eserleri 1 (İstanbul: Gözde Yayınları, 1980), 262-266; Küçük Osmanlı'nın Öyküsü, 94. 44 Şekaik-ı Numaniye ve Zeyilleri Vekâyiu'l-Fudalâ, 1/ 179; İ. Hakkı Uzunçarşılı, Osmanlı Tarihi (Ankara: Türk Tarih Kurumu, 1988), 3/241; Vekâyi'nâme, 10; Küçük Osmanlı'nın Öyküsü, 96; Özcan, “Safranbolu'da Üç Şahsiyet”, 118.

45 Târîh-i Naîmâ, 3/1176-1177; Evliya Çelebi Seyahatnâmesi, 2. Kitap/ 248; İ. Hakkı Uzunçarş1lı, Osmanlı Tarihi, 3/241. Mihaliç'e sürgün edildiği de belirtilmektedir, bk. Şekaik-ı Numaniye ve Zeyilleri Vekâyiu'l-Fudalâ, 1/179; Kara Çelebi-zâde Abdülaziz Efendi, Ravzatü'l-Ebrâr Zeyli (Tahlîl ve Metin) (Ankara: Türk Tarih Kurumu, 2003), 18; İahlı Osmanlı Tarih Kronolojisi, 3/413; Fezleke, $2 /$ 341; Vekâyi'nâme, 10.

46 Târîh-i Naîmâ, 3/1177; Netâyicü'l-Vukū'ât, 261; Fezleke, 2/341; Fakihler ve Sofularnn Kavgasl, 43.

47 Târîh-i Naîmâ, 3/1177; Hulusi Yazıcıŏ̆lu, Safranbolu Tarihine Ait Belgeler ve Kaynaklar (Ankara: Safranbolu Hizmet Birliği Kültür Yayınları, 1998), 43. Bir rivayete göre Mısır'a sürülmüş, fakat Kırım hanının tavassutuyla İstanbul'a dönmüştür, bk. Tarihî Sîmalar Tesâvîr-i Ricâl, 63.

48 Şekaik-ı Numaniye ve Zeyilleri Vekâyiu'l-Fudalâ, 1/179; Atatürk Kitaplığı Müteferrik Evrak, 60826; Evliya Çelebi Seyahatnâmesi, 2. Kitap/248; Netâyicü'l-Vukū 'ât, 243; Naîmâ Tarihi, 3/1177; Vekâyi'nâme, 10; Kâmusu'l-A'lâm, 3/1840; “Safranbolu'da Üç Sahsiyet”, 117-119; Muhibbî, Hülâsatü'l-Eser, 2/123; "Osmanlı Tarihinin Rasputini Cinci Hoca Hüseyin Efendi," 2/1179; Şefaattin Deniz, Safranbolulu İzzet Mehmed Paşa ve Dönemi (İstanbul: Bilge Kültür Sanat Yayını, 2016), 24; Ahmet Refik Altınay, Tarihî Sîmalar Tesâvîr-i Ricâl, 69-70; Aksoy, Kuş Aytekin, Müze Kent Safranbolu, 14. Evliya Çelebi, Sultan İbrahim Han Vezir Hezârpâre Ahmed Paşa ve Cinci Hoca'nın katlini anlattığı başlıkta: "tâbe serâhümâ rahmetullahi aleyhim ecmaîn" şeklinde dua cümlesi ilave etmitir, bk. Evliya Çelebi Seyahatnâmesi, 2. Kitap/246.

Türkiye İlahiyat Araştırmaları Dergisi 
âkibetten kurtulamamıştır. ${ }^{49}$ Torunlarından birinin ifadesine göre kabri Yeşil türbenin kapısı yanında bulunmaktadır. ${ }^{50}$ Cinci Hüseyin Efendi uluvv-i himmetiyle meşhur, servet sahibi olmakla maruf, döneminde sözünün geçmesiyle mevsuf, bahtının açık olması sayesinde herkesin arzu ettiği makam olan kazaskerliğe vâsıl ve büyük bir servete nâil kişi olarak tanımlanmıştır. ${ }^{51}$

\section{Hüseyin Efendi'nin Kişiliği}

Cinci Hoca olarak meşhur olan Evliya Çelebi ve Mehmed Halife gibi müellifler tarafından cahil olarak nitelendirilen ${ }^{52}$ Hüseyin Efendi, Sultan İbrahim'in gözdelerinden Şekerpâre Kadın ve Silahtar Yusuf Ağa sayesinde padişah üzerinde önemli bir nüfuz sahibi olmuştur. Dönemin siyasi hadiselerinin içinde bulunmuş, vazife tevcihlerinde belirleyici rol oynamış, kendisine engel ve karşı olan Kemankeş Kara Mustafa Paşa, Faik Paşa gibi devlet adamlarının katledilmesinde etkili olmuştur. Tarihi kaynaklarda vezir Kemankeş Kara Mustafa Paşa zamanında korkusundan saraya ve sultana yanaşmazken ondan sonra sultana yakınlaşmış, ikbali açılmış ve büyük bir servet sahibi olmuştur. ${ }^{53}$ Diğer taraftan usûlsüz olarak müderrislik pâyesi verilmesine karşı çıkan Şeyhülislam Zekeriya-zâde Yahya Efendi'nin itibarını sarsmış, mal mülk kazanma hırsıyla birçok yolsuzluklar yapmıştır. Kayınpederi Karaçelebi-zâde Mahmud Efendi'nin de desteğiyle kadıaskerliği zamanında ilmiyeye ait görevleri/mansıpları rüşvet karşılığında satarak, kısa zamanda Karun'un hazînelerini andıracak büyüklükte bir servet edinmiştir. Böylece Kazasker Hüseyin Efendi XVII. yüzyılın dikkat çeken önemli simalarından biri haline gelmiştir. ${ }^{54}$

49 Târîh-i Naîmâ, 3/1160; Târih-i Siyâsi Devlet-i Aliyye-i Osmâniyye, 2/89.Abdulkadiroğlu - Özsoy, Safranbolu Meşhurları, 89.

50 “Osmanlı Tarihinin Rasputini Cinci Hoca Hüseyin Efendi,” 2/1179.

51 Şekaik-ı Numaniye ve Zeyilleri Vekâyiu'l-Fudalâ, 1/179.

52 Evliya Çelebi Seyahatnâmesi, 2. Kitap/247; Mehmed Halife, Tarih-i Gllmân̂̂̀ं̇stanbul: Tercüman Gazetesi, Tarihsiz), 45; Küçük Osmanlı'nın Öyküsü, 93; Yazıcıŏlu, Safranbolu Tarihine Ait Belgeler ve Kaynaklar, 43.

53 Tarih-i Nâimâ, 3/ 975-977, 1060, 1068; Vekâyi'nâme, 10; Târih-i Gılmânî, 24, 26; Evliya Çelebi Seyahatnâmesi, 2. Kitap/83; "Yeniçeriler", 5/91. Hatta bir kaynakta: "Sultan İbrahim'e duhul ve ervâh-1 habise gibi hulûl eden" olarak tavsif edilmiştir, bk. Ravzatü'l-Ebrâr Zeyli (Tahlîl ve Metin), 20. Mimar Kasım Ağa'nın mimarbaşı olmasında Cinci Hüseyin Hoca etkili olmuştur, zira Kasım Ağa'nın vaktiyle yüz altın vererek kendisine yaptığı iyiliği unutmamıştır, bk. Târîh-i Naîmâ, 3/1025-1026.

54 Ravzatü'l-Ebrâr Zeyli (Tahlîl ve Metin), 15; "Safranbolu'da Üç Sahsiyet", 117-119; Vekāyiu'lFudalâ 1/178-179; “Hüseyin Efendi, Cinci Hoca,” 18/541-543.

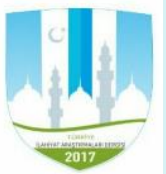




\section{Hüseyin Efendi'ye Yapılan Temlikler}

Temlik, bir hükümdarın sultanlık yetkisini kullanarak mîrî araziden veya şahıslardan devlete intikal eden arazi ve binalardan bazı yerleri devlete hizmet etmiş kimselerden istediklerine mülk şeklinde tahsis etmesidir. Yapılan tahsisata ilişkin belgeye de temliknâme/mülknâme denilmektedir. ${ }^{55}$ Temlik edilen mülkler, mülknâme-i hümâyun ve temlîk-i sahîh ile yapılmışsa vakfa dönüştürülmesi mümkün görülmüştür. ${ }^{56} \mathrm{Bu}$ çerçevede kurulmuş veya kurulacak olan bir vakfa gelir kaynağı sağlamak için temlikler yapıldığını gösteren birçok örnek bulunmaktadır. ${ }^{57}$ Temlik edilen arazilerin Defterhâne-i Âmire'deki kayıtları düzeltildikten sonra kadı ve bölgenin ileri gelenlerinden oluşturulan komisyonlar tarafından yerinde yapılan tespitle temlik edilen köylerin sınırlarını belirten sınırnâme düzenlenmiştir. ${ }^{58}$

Osmanlı sultanları birtakım yerleri bütün haklarıyla nesilden nesile intikal edecek şekilde istedikleri kişilere bedelsiz bağışlamak suretiyle kendilerinde temlik etme hakkını görmüşlerdir. Sultan İbrahim de Anadolu Kazaskeri Hüseyin Efendi'ye (Cinci Hoca) 66.925 akçe $^{59}$ geliri olan o dönemde Bolu sancağına bağlı köyleri bütün hak ve resimleriyle ebediyet kaydıyla temlik etmiştir. Temliknâmenin girişinde seleflerinin bir kısım ulemâya arazi ve köyleri temlik ettikleri gibi Sultan İbrahim de dini meseleleri halletmesi, hakikat hazinelerinin anahtarı, ulemânın en bilginlerinden, din ve devlete müteallik pek çok iyiliklere ve güzelliklere vesile olması sebebiyle izzet ve ikrama layık olduğundan, Anadolu Kazaskeri Hüseyin Efendi'ye bazı pâye ve makamların yanı sıra deftere kaydedilen köyleri ve arazileri mülk olarak vermiştir. ${ }^{60}$ Böylece söz konusu köyler hatt-1 hümâyûn ile Hüseyin Efendi adına temlik olunmuştur. Buna binaen defter-i icmalde mülkiyet şeklinde kaydı düzeltilerek Hüseyin Efendi'ye mülk-nâme-yi hümâyûn verilmiştir. ${ }^{61}$

Tablo 1: Hüseyin Efendi'ye Temlik Edilen Köyler ve Gelirleri

\begin{tabular}{|l|l|}
\hline Birimin Adı & Geliri (akçe) \\
\hline
\end{tabular}

\footnotetext{
55 Ömer Lütfi Barkan, Türkiye'de Toprak Meselesi Toplu Eserleri 1, 260; Mehmet İpşirli, "Temliknâme", Türkiye Diyanet Vakfı İslâm Ansiklopedisi (Ankara: Türkiye Diyanet Vakfı, 2011), 40/430.

56 Ömer Lütfi Barkan, Türkiye'de Toprak Meselesi 1, 261; “Temliknâme,” 40/ 431.

57 Ömer Lütfi Barkan, Türkiye'de Toprak Meselesi, 261-262.

58 BOA, TT. d, No. 783. Evâhır-1 Cemâziyelâhır 1054/Ağustos-Eylül 1644.

59 Defterdeki kayıtların toplamı 67.090 akçe olarak hesaplanmaktadır, bk. BOA, TT. d, No. 783, $2 b$.

60 BOA, TT. $d$, No. 783, 15-16.

61 BOA, TT. d, No. 783, 2. Evâhır-ı Cemâziyelâhır 1054/Ağustos-Eylül 1644.
}

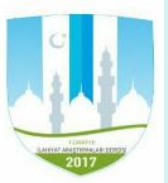

Türkiye İlahiyat Araştırmaları Dergisi

Turkey Journal of Theological Studies

ISSN: 2602-3067

[Tiad] 


\begin{tabular}{|c|c|}
\hline Taraklıborlu Nahiyesi (5 köy) & \multirow{6}{*}{18.500} \\
\hline Konar1 & \\
\hline Kuzyaka/Kuzyaka & \\
\hline Çerçen & \\
\hline Kirpe & \\
\hline Sakaralanı (?) & \\
\hline Yazıköyü & 9.150 \\
\hline Öküzviran & 5000 \\
\hline $\begin{array}{l}\text { Yörükân-1 Keçibeyli (Borlu Nâhiyesinde } \\
\text { kışlarlar) }\end{array}$ & 3.227 \\
\hline \multicolumn{2}{|l|}{ Viranşehir Nâhiyesi } \\
\hline Tutaş & 259 \\
\hline Tutan & 216 \\
\hline Çomakal (?) & 1.498 \\
\hline Gökej (?) & 526 \\
\hline Semayil & 1.850 \\
\hline \multicolumn{2}{|l|}{ Onikidivan Nâhiyesi } \\
\hline Ulugeçit & 2.000 \\
\hline \multicolumn{2}{|l|}{ Taraklıborlu Nâhiyesi } \\
\hline Bürnük & 5.849 \\
\hline \multicolumn{2}{|l|}{ Bolu Nâhiyesi } \\
\hline $\begin{array}{l}\text { Mezraa-i İbrahim (Zamüddin } \\
\text { Karyesinde) }\end{array}$ & 150 \\
\hline \multicolumn{2}{|l|}{ Taraklıborlu Nâhiyesi } \\
\hline Bulanık Mezraası & 1.500 \\
\hline \multicolumn{2}{|l|}{ Onikidivan Nâhiyesi } \\
\hline Eshater (?) & 7.375 \\
\hline Ulugeçit & 2.620 \\
\hline \multicolumn{2}{|l|}{ Borlu Nâhiyesi } \\
\hline Berk ve Çakşe (?) & 1.830 \\
\hline Elçin (?) & 3.185 \\
\hline \multicolumn{2}{|l|}{ Borlu Nâhiyesi } \\
\hline Pınarcıközü & 2.355 \\
\hline Toplam & 67.090 \\
\hline
\end{tabular}

Yukarıda adı geçen 67.090 akçe gelire sahip zeâmet ve tımarlı köyler, mezraalar ve bunların sınırları dahilindeki araziler, meralar, dağlar-tepeler, ağaçları, nehirleri bütün hakları ve buralara bağlı yerler her şeyiyle, yâve, kaçgûn, bâd-1 hevâ, cürm ü cinâyet, resm-i ganem, öşür gibi şerî ve örfi vergileriyle devlet bütçesine veya hazine-i hassaya ait belirlenmiş osun belirlenecek olsun bütün gelirleriyle Hüseyin Efendi'nin mülkü olarak tescil edilerek, kendisinin ve soyundan gelenlerin nesilden nesile mutasarrıf olması hükme bağlanmıştır. ${ }^{62}$ 
Hüseyin Efendi, mülkü haline dönüştürülen bu arazileri istediği şekilde tasarrufta bulunma hakkına sahiptir; dilerse satabilir, başkasına bağışlayabilir, isterse vakfedebilir. Herhangi bir sebep ve gerekçeyle hiç kimsenin tasarrufuna engel olmaması, yapılan bu temlikin bozulmaması ve tatil edilmemesi kayda geçirilmiştir. Her kim bu mülkiyeti bozmaya ve değiştirmeye kalkarsa günahı değiştirenlerin üzerinedir.63 Mülknâmenin padişahın tuğrası, veziriazam, vezirler, Rumeli kazaskeri, defterdar ve kâtiplerin imzalarıyla kanunlara uygun olduğu onaylanmıştır. ${ }^{64}$

Sultan İbrahim, Hüseyin Efendi'ye Bolu sancağına bağlı Bolu ve Taraklıborlu ve Viranşehir ve Kızılbel ve Eflani, Onikidivan ve Şehabeddin ve Küçnovi (?) ve Divrikan kazalarında sınırları belirlenen arazileri mülkname ile temlik ve ihsan etmesi üzerine toprak kadılarına bir emir yazılmıştır. ${ }^{65} \mathrm{Bu}$ emirnâmede âdil ve tarafsız kişiler huzurunda hudutları ve sınırları belirlenen ve Hüseyin Efendi'ye mülknâme-i hümâyun ve hatt-1 hümâyunla Sultan İbrahim tarafından temlik edilmiş köyler/arazilerin miktarı, mutasarrıfları ve gelirlerinin miktarları şöyledir: 66

Tablo 2: Hüseyin Efendi'ye Temlik Edilen Arazilerin İsmi, Mutasarrıfları, Miktar1.

\begin{tabular}{|c|c|c|}
\hline Birimin Ad1 & Geliri (akçe) & Mutasarrıfı \\
\hline \multicolumn{3}{|l|}{ Bolu } \\
\hline İlmen & $\begin{array}{l}10 \\
\text { dönüm/2.707 }\end{array}$ & $\begin{array}{l}\text { Dergâh-1 mualla çavuşlarından } \\
\text { Mehmed ve Anadolu } \\
\text { çavuşlarından Ömer ve Mustafa } \\
\text { ve Akif Çavuş }\end{array}$ \\
\hline Güğümsu mezraası & $\begin{array}{l}13 \\
\text { dönüm/4.541 }\end{array}$ & $\begin{array}{l}\text { Dergâh-1 mualla görevlileri Ömer } \\
\text { ve Osman ve serasker Hasan, } \\
\text { Mustafa ve Ali }\end{array}$ \\
\hline İlmen & $\begin{array}{l}7 \\
\text { dönüm/2.152 }\end{array}$ & İki Mehmed çavuş \\
\hline
\end{tabular}

63 BOA, TT. d, No. 783, 2-3. Evâhır-1 Cemâziyelâhır 1054/Ağustos-Eylül 1644. Temliknâmenin sonunda bunu değiştirmeye teşebbüs edenler Bakara, 2/181 âyeti ile tehdit edilmektedir.

64 BOA, TT. d, No. 783, 3.

65 Hamdele, salvele ve ashâb-1 kirâmı tazimden sonra Rumeli pâyesiyle Anadolu kazaskeri olan Hüseyin Efendi'nin Anadolu'da Bolu sancağında Taraklıborlu'da bina ve inşa ettirdiği cami ve imâret-i cedide-i âmirenin mühimmât-ı mesâlihi ve tekmiât-ı levâzımı için Taraklıborlu, Bolu, Viranşehir, Eflani, Onikidivan, Küçnovi, Kızılbel, Şehabeddin ve Yörükân-1 Taraklıboru kazalarında vaki olup, vakf ve temlik ettiği kurânın eyyâm-ı sâlife ve a'vâm-ı sâbıkadan beri mamûl-i bahâ olan hudut ve merasimin malum edinip, lazım ve emr-i mühim olan yerlere alâmât-ı zâhire vaz edesin deyu bu abd-i fakire ve kazâ-i mezbûre kadılarına fermân olunduğundan bu emre imtisâlen zikr olunan kazalarda vaki kura-i müteferrikanın alâ ceddihi üzerlerine varılıp ehâlî-i vilâyette teayyün ve ayân-ı memleket tahkik ve tebeyyün ettikleri tefâsîli âtiye üzere kurâ-i mevkûfe-i mersûmenin hududu ve reâyâları ve muâfiyetleri budur ki zikrolunur denilmektedir, bk. BOA, TT. $d$, No. 783, 18a.

66 BOA, TT. $d$, No. 783, 3-7.

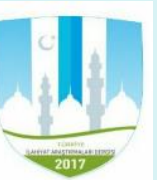

Türkiye İlahiyat Araştırmaları Dergisi

Turkey Journal of Theological Studies

ISSN: 2602-3067

[Tiad] 


\begin{tabular}{|c|c|c|}
\hline $\begin{array}{l}\text { Dadyem/Dadim ve } \\
\text { Bozgan/Yozgat }\end{array}$ & 5.637 & İki Mehmed çavuş \\
\hline Birgi & $\begin{array}{l}52,5 \\
\text { dönüm/6.166 }\end{array}$ & \\
\hline İzzet veya Kuğum & 6.166 & Mehmed, Süleyman ve Mustafa \\
\hline Veled-i Sufi Hızır & 2.749 & Mehmed çavuş ve Hasan \\
\hline İlmen & 27 dönüm & \\
\hline İzzet & 5.500 & Mehmed ve Abdülkadir \\
\hline İlmen & 2 dönüm & \\
\hline $\begin{array}{l}\text { Kayrazdivan } \\
\text { Gökpınar }\end{array}$ & 3.000 & Ferhad ve İbrahim \\
\hline Birgi & 8 dönüm/ & \\
\hline Gökpınar & 4.900 & Mehmed ve Mustafa \\
\hline Çömlekci & 3.433 & Ayişe \\
\hline Birgi & 15 dönüm/ & \\
\hline \multicolumn{3}{|l|}{ Viranşehir } \\
\hline Semayil & 800 & Mehmed ve Faysal \\
\hline \multicolumn{3}{|l|}{ Taraklıborlu } \\
\hline Değirmencik & 1.729 & Mustafa ve Ahmed ve İsmail \\
\hline $\begin{array}{l}\text { Koçari (?) ve } \\
\text { Geçenbeyli }\end{array}$ & & Fahkal (?) isimli köylüler \\
\hline \multicolumn{3}{|l|}{$\begin{array}{l}\text { Geçine ve } \\
\text { Karyekoz içmeleri }\end{array}$} \\
\hline \multicolumn{3}{|l|}{ Kılavuzlar çayırı } \\
\hline Tutaş & 1.746 & $\begin{array}{l}\text { Abdülcelil ve Alihan ve İbrahim } \\
\text { çavuş }\end{array}$ \\
\hline Gökviran & $\begin{array}{l}17 \\
\text { dönüm/6.606 }\end{array}$ & Hasan ve Ayal ve Halil \\
\hline Öküzviran & 30 dönüm/ & \\
\hline Kad1 & 2.586 & Mehmed ve İbrahim ve Mustafa \\
\hline \multicolumn{3}{|l|}{ Oniki divan } \\
\hline Ulugeçit & 1.519 & $\begin{array}{llll}\begin{array}{l}\text { Abdülkadir ve Mehmed ve } \\
\text { Mustafa }\end{array} & & \\
\end{array}$ \\
\hline Doğanc1 & 615 & Mehmed \\
\hline \multicolumn{3}{|l|}{$\begin{array}{l}\text { İlmen nam-1 diğer } \\
\text { Kuzkilim }\end{array}$} \\
\hline Akkocal1 & 385 & \\
\hline Birk & $\begin{array}{l}17 \\
\text { dönüm/4.500 }\end{array}$ & Yörükân köyleri \\
\hline \multicolumn{3}{|l|}{ Kehma Nahiyesi } \\
\hline Karacaağaç & 3.015 & Mahmud \\
\hline Birgi & 42 dönüm/ & \\
\hline \multicolumn{3}{|l|}{ Taraklıborlu } \\
\hline $\begin{array}{l}\text { Üveyli Yeleği } \\
\text { (?)/Budinlik }\end{array}$ & 2.000 & $\begin{array}{l}\text { Fethullah, Hüseyin, diğer } \\
\text { Hüseyin ve Hasan }\end{array}$ \\
\hline
\end{tabular}

Türkiye İlahiyat Araştırmaları Dergisi

Turkey Journal of Theological Studies

[Tiad: 2602-3067]
Cilt / Vol: 5,

Sayi/Issue: 2 2021 


\begin{tabular}{|c|c|c|}
\hline $\begin{array}{l}\text { Viranşehir } \\
\text { Nahiyesi }\end{array}$ & & \\
\hline Yalak & 1.100 & \\
\hline Kartık ve .... (?) & 4.999 & $\begin{array}{l}\text { Ahmed, Abdulaziz, Mehmed, } \\
\text { Hasan, İyal ve Yahya }\end{array}$ \\
\hline \multicolumn{3}{|l|}{ Tarakliborlu } \\
\hline Kizılcaviran & 6.077 & İbrahim çavuş ve alaybeyi Osman \\
\hline Budnik & 500 & \\
\hline Sakaralan & 5.000 & \\
\hline \multicolumn{3}{|l|}{ Çiftlik-i Akıncı } \\
\hline \multicolumn{3}{|l|}{ Dörtdivan Ulugeçit } \\
\hline \multicolumn{3}{|l|}{$\begin{array}{l}\text { Çiftlik-i Mehmed } \\
\text { Usta }\end{array}$} \\
\hline \multicolumn{3}{|l|}{ Çiftlik-i Pınarcık } \\
\hline \multicolumn{3}{|l|}{$\begin{array}{ll}\text { Onikidivan } & \text { ve } \\
\text { Çiftlik-i Öküz } & \\
\end{array}$} \\
\hline $\begin{array}{l}\text { Mansuriye tabi } \\
\text { Eflani }\end{array}$ & & Kâtip Mehmed \\
\hline Budnik & & Muslihiddin Ağa \\
\hline \multicolumn{3}{|l|}{ Tutaş } \\
\hline \multicolumn{3}{|l|}{ Karye-i Seferşah } \\
\hline \multicolumn{3}{|l|}{$\begin{array}{l}\text { Çiftlik-i Söndük/ } \\
\text { Budnik }\end{array}$} \\
\hline Kuzukulak & & Muslihiddin Ağa \\
\hline \multicolumn{3}{|l|}{ Çiftlik-i Pınarcık } \\
\hline \multicolumn{3}{|l|}{ Mezraa-i Doğandır } \\
\hline \multicolumn{3}{|l|}{ Kurukuzu } \\
\hline \multicolumn{3}{|l|}{ Karaağaç } \\
\hline Pinarcik & & İsa Bey \\
\hline \multicolumn{3}{|l|}{ Bolu Nahiyesi } \\
\hline Gökçesu & $5 \mathrm{müd} / *$ & İmam Yunus \\
\hline \multicolumn{3}{|c|}{\begin{tabular}{l|l} 
Alpanagud Şahin & \\
Bey mezraası &
\end{tabular}} \\
\hline \multicolumn{3}{|l|}{$\begin{array}{l}\text { Taraklıborlu } \\
\text { Nahiyesi }\end{array}$} \\
\hline Kuznik & 250 & Aygad Ağa \\
\hline \multicolumn{3}{|l|}{$\begin{array}{l}\text { Onikidivan } \\
\text { Nahiyesi }\end{array}$} \\
\hline Ulu Mecid & On beş müd & Bayezid Hüdavendigar vakfı \\
\hline Budnik & & \\
\hline
\end{tabular}

* Müd: Osmanlı döneminde ağırlık ölçüsü olarak kullanıldığı gibi ekilebilir arazi için de kullanılan bir tabir olup, bölgeden bölgeye ve arazinin verimine göre değişmektedir. 935/1528 tarihli Karaman Vilâyeti Kanunnâmesi'ne göre verimi yüksek yerden 60, orta yerden 80-90 ve az olan yerden 100-120 dönüm şeklinde tanımlanan "çiftlik" halk arasında Bursa'nın 12, Konya'nın 8 ve Karaman'ın ölçüsüne göre 6 müdlük bir alanı ifade etmektedir, bk. Cengiz Kallek, "Müd”, Türkiye Diyanet Vakfı İslâm Ansiklopedisi (İstanbul: Türkiye Diyanet Vakfı, 2006), 31/457-459.

\section{Türkiye İlahiyat Araştırmaları Dergisi}




\begin{tabular}{|l|l|l|}
\hline $\begin{array}{l}\text { Taraklıborlu } \\
\text { kasabası }\end{array}$ & 19.963 & $\begin{array}{l}\text { Şerî ve örfî vergileri temlik } \\
\text { edilmiştir }\end{array}$ \\
\hline Bulak & 16.292 & \\
\hline Altıviran & 6.924 & \\
\hline Onikidivan & 5.000 & \\
\hline Ulugeçit & 6.166 & \\
\hline Bolu/İzzet & 12.868 & \\
\hline $\begin{array}{l}\text { Eflani/Akpınar } \\
\text { Kehnus/Keçi } \\
\text { deresinde içmeler }\end{array}$ & & \\
\hline $\begin{array}{l}\text { Yazı ve Bulak adlı } \\
\text { köyler }\end{array}$ & & \\
\hline
\end{tabular}

Yapılan temlikin bağlayıcılığı ve tasarruf hakkına ilişkin husus da açıkça belirlenmiştir. Nitekim yukarıda zikredilen köyler ve mezraların hudut ve sınırları dahilinde olup, ifraz ve ihracı mümkün olmayan has, tımar, mülk veya vakıf arazilerin tamamı, hatt-1 hümâyunla Hüseyin Efendi'ye hibe ve temlik edilmiş, icmal ve mufassal defterlerdeki kayıtlar nişancı tarafından temlike binaen tashih olunmuştur. Diğer emlak ve arazi sahipleri, mülklerini tasarruf konusunda hangi haklara sahip ise, Hüseyin Efendi de adı geçen köy, mezraalar ve bunların içinde yer alan arazi, mera, dağ-tepe, ağaçlar, nehirler/akarsularla belirlenen ve belirlenecek olan bütün şerî ve örfi vergileriyle kıyamete kadar mülkü olup, dilediği gibi tasarruf hakkına sahiptir. Temlik edilen bu emlak, kendisinden sonra da nesilden nesile evlatlarına intikal edecektir. Dilerse satar, dilerse başkasına bağışlar, dilerse vakfedebilir. Hiçbir sebeple veya herhangi bir şekilde kimse Hüseyin Efendi'nin istediği gibi tasarruf etmesine mâni olmayacaktır. Her kim bu mülknameyi/temliki iptal etmeye, değiştirmeye ve başka bir şekle dönüştürmeye kalkışacak olursa ${ }^{67}$ Allah'ın cezasına/azabına mazhar olup dünya ve ahirette/dâreynde mahcub olsunlar şeklinde beddua edilmektedir. Alâmet-i şerife itimat kilsınlar, mazmun-i hümâyûnum muhakkak ve musaddak bilip itimad-1 tâm itikâd-1 meâl-i kelam kılalar. Bu temliknâmenin kanuna ve usule uygun olduğu başta veziriazam, diğer vezirler, defterdar ve tevkiî tarafından tasdik edilmiştir. ${ }^{68}$

\subsection{Temlik Edilen Köyler}

Kazasker Hüseyin Efendi'ye temlik edilen Kirpe, Konari, Keçibeli, Akviran, Kadıbükü, Çeçen, Kuzyaka, Kılavuzlar, Semali, Karabük, İshak, Tutaş,

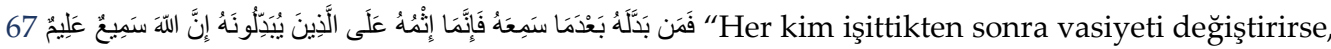
günahı ancak onu değiştirenlerin boynunadır", Bakara 2/181.

68 BOA, TT. d, No. 783/1-7. Evâhır-1 Rebîulûlâ 1055/16-26 Mayıs 1645.

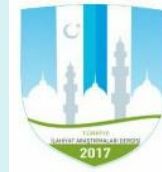


Çomaklar, Göğer, Pınarcıközü, Öküzviran, İlmen, Kuzkili, Yunuslar, Kuğum, Ulugeçit, Berk, Çakşe, Pulat, Alınviran, Davudobası, Ömer Sofi ve Memikli köylerinin sınırları tapu kayıtlarında ayrıntılı olarak belirlenmiştir. ${ }^{69}$

Buna istinaden temlik edilen yerlerin sınırlarını gösteren bir sınırnâme düzenlenmiştir. Bu sınırnâme yerinde tarafsız kişiler tarafından tescil ve tahrir edilmiştir. Başta Uluborlu kadısı el-Hac Abdülvehhab olmak üzere temlik edilen kaza kadıları heyetler oluşturarak, köylerin sınırlarını yerinde tayin ve tespit etmişlerdir. ${ }^{70}$ Buna göre, Taraklıborlu kazasında Yazı isimli köyün sınırı, şehirden gelen Uluyol altında vakıf deresini takip ederek Havaclihan (?) deresine, oradan yine dere boyunca Çörtükçü (?) denilen yere, oradan dere yanı sıra Araç ırmağına, oradan ırmağı takip ederek Köklü köprüsüne, oradan Değirmen deresi çayı sıra Gökçiflik deresine, oradan çayın yanı sıra Kırkpınar dere bendine, oradan Irgatyolunu takip ederek adı geçen vakıf deresine kadar olan yerleri kapsamaktadır. ${ }^{71}$ Diğer köylerin sınırları da benzer usulle tayin ve tespit edilmiştir. Bunların tamamına burada yer vermek bu makalenin hacmini aşacağından bir örnekle yetinilmiştir.

\subsection{Hüseyin Efendi'ye Tanınan Muâfiyetler}

Kazasker Hüseyin Efendi'ye temlik edilen köy, mezraa ve çiftliklerde sakin olan ve toprakları işleyenlerin vermekle mükellef oldukları vergiler bulunmaktaydı. $\mathrm{Bu}$ arazilerin Hüseyin Efendi'ye temlik edilmesiyle kendi mülkü gibi tasarruf hakkına sahip olan Hüseyin Efendi, bütün vergilerden muaf tutulmuştur. $\mathrm{Bu}$ çerçevede adı geçen emlâkin reâyâsı Osmanlı vergi sistemi içinde yer alan avârız-1 divâniyyeden ${ }^{72}$, tekâlif-i örfiyye ${ }^{73}$ ve şâkkadan ${ }^{74}$, bedel-i mekkâri"

69 BOA, TT. $d$, No. 783.

70 BOA, TT. $d$, No. 783-8b.

71 BOA, TT. $d$, No. 783

72 Avârız-1 divaniye: Avârız-ı divaniye: Osmanlı Devleti'nde Tanzimat'a kadar fevkalade durumlarda ve özellikle sefer masraflarını karşılamak için, reayadan alınan vergidir, bk. Ömer Lütfi Barkan, “Avârız”, İslam Ansiklopedisi, (İstanbul: Milli Eğitim Basımevi 1961), 2/13-19.

73 Tekâlîf-i örfiyye: Osmanlılarda özellikle savaş dönemlerinde ihtiyaca göre daha çok hâne, aile, çift, ocak gibi bir esasa dayalı olarak konulan vergiler için kullanılan bir tabirdir, bk. Ahmet Tabakoğlu, "Tekâlif", Türkiye Diyanet Vakfı İslam Ansiklopedisi (İstanbul: Türkiye Diyanet Vakfı, 2011), 40/336-337.

74 Tekâlîf-i şâkka: Tekâlif-i örfiyye içinde sayılan ve birçok vergi çeşitlerini içeren genellikle memurların halktan aldıkları vergiler için kullanılan bir kavramdır, bk.Tabakoğlu, "Tekâlif", 40/336-337.

75 Bedel-i mekkârî: Savaş zamanlarında taşımacılıkta kullanılmak üzere kiralanan hayvanlar için halktan alınan verginin adıdı, bk. Ömer İşbilir, "Mekkâre", Türkiye Diyanet Vakfi İslâm Ansiklopedisi (Ankara: Türkiye Diyanet Vakfı, 2003), 28/554-555.

Türkiye İlahiyat Araştırmaları Dergisi

Turkey Journal of Theological Studies

ISSN: 2602-3067

[Tiad] 
bedel-i sürsat ${ }^{76}$, bedel-i nüzûl ${ }^{77}$ ve benzeri vergilerin tamamından muaf sayıldıkları gibi beylerbeyi ve sancakbeyi tarafından selamiye ve nakl-i baha ve devr akçesi ve subaşı ve çeribaşı ve yağ ve bal ve arpa ve saman ve odun ve koyun ve kuzu ve tavuk ve ördek ve güvercin teklifinden ve tersâne-i âmireye müteallık gemi kerestesi ve zift ve körük ve seren ve top arabası mühimmatı teklifinden ve konuk ve köçek akçesi teklifinden ve bedel-i siyaset ve öşr-i diyet akçesinden ve hisar yapmaktan ve ulaktan ve suhreden ve cizye horden ve kılavuzluk alınmaktan istisna tutulmuşlardır. Ayrıca yerlerinden kaldırılmamaları, resm-i bennâk ${ }^{78}$, resm-i çift ${ }^{79}$ ve çift bozan ${ }^{80}$ adı altında para alınmaması ve hiçbir surette müdahalede bulunulmaması konusunda muafnâme verilmiştir..$^{81}$ Bundan sonra gerek sultan dahil her kademeden devlet ricalinden gerek başkaları tarafından hiçbir sebeple ve hiçbir gerekçeyle müdahale edilmemesi kayıt altına alınmıştır. ${ }^{82}$ Bunu değiştirmeye kalkanlar: "Kim vasiyeti işittikten sonra değiştirirse, bunun günahı değiştirenin üzerinedir. Allah şüphesiz işitir ve bilir" âyeti gereği azabın şiddetlisine maruz kalsınlar, her iki cihanda yüzleri kara olsun, gazaba uğrasınlar denilmektedir. ${ }^{83}$

\section{Hüseyin Efendi'nin Yaptırdı̆̆ı Eserler}

Bilindiği üzere Cinci Hoca lakabıyla anılan Hüseyin Efendi, şehzadeliği döneminde yaşadığı korku dolu yılların verdiği ruhi rahatsızlıklardan Sultan I. İbrahim'i iyileştirerek padişah nezdinde önemli bir mevki kazanmış ve kazaskerlik makamına kadar yükselmiştir. Padişaha yakınlığını ve sahip olduğu kazaskerlik makamını kullanarak kısa zamanda önemli bir servetin sahibi olmuştur. Sahip olduğu mülk ve zenginlik sayesinde İstanbul'da ve memleketi Safranbolu'da saraylar, han, hamam gibi birçok eser vücuda getirmiştir.

\subsection{Cinci Hanı}

76 Bedel-i sürsat: Sefere giden ordunun zahire bedeline karşılık alınan vergiyi ifade etmektedir, bk. Midhat Sertoğlu, Osmanlı Tarih Lîgatı (İstanbul: Enderun Yayınları, 1986), 319.

77 Bedel-i nüzul: Osmanlı döneminde hububattan alınan bir avârız vergisidir, bk. Ömer İşbilir, “Nüzül”, Türkiye Diyanet Vakfı İslâm Ansiklopedisi (İstanbul: Türkiye Diyanet Vakfı, 2007), 33/311312.

78 Resm-i bennâk: Evli çiftçilerden alınan arazi vergisidir, bk. Sertoğlu, Osmanlı Tarih Lîgatı, 74.

79 Resm-i çift: Örfî vergilerden olup, araziyi eken çiftçilerden alınmaktaydı, bk. Sertoğlu, Osmanlı Tarih Lûgatı, 74.

80 Çift bozan: Herhangi bir sebeple ziraatı terk edenlerden alınan verginin adıdır, bk. Sertoğlu, Osmanlı Tarih Lûgatı, 74 .

81 BOA, TT. $d$, No, 783, 10-16.

82 BOA, TT. d, No, 783, 16b-18a. Evâhır-1 Rebîulevvel 1055/Mayıs 1645.

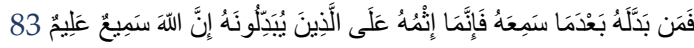

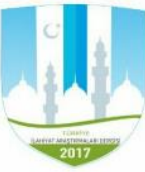


Tarih boyunca ticaret kervanlarının yolları üzerinde bulunan Safranbolu'da Cinci Hanı olarak bilinen iki katlı han, konaklama ve ticaret merkezi olarak işlev görmüştür.

Safranbolu'da XII. yüzyıl eserlerinden olan Cinci Hanın her ne kadar kitabesi bulunmadığ i için Anadolu Kazaskeri Hüseyin Efendi tarafından yaptırıldığının kesin olarak bilinmediği ifade edilmekteyse de ${ }^{84}$ Cinci Hoca tarafından mükemmel bir han olarak yaptırıldığı kabul edilmektedir..$^{85}$

Hüseyin Efendi'nin doğum yeri Safranbolu'da yaptırdığı Cinci Hoca Hanı Mimar Kasım tarafından inşa edilmiştir. ${ }^{86}$ Yapıldığı tarih kesin olarak bilinmemekle birlikte, Cinci Hoca'nın ikbal devirlerinde (1644-1648 yılları) yapıldığ 1 tahmin edilmektedir. Annesi Hâmide Hatun adına ${ }^{87}$ tanzim edilen vakfiyesi 15 Safer 1055/12 Nisan 1645 tarihini taşımaktadır. ${ }^{88}$ Cinci Hanı iki katlı tek avlulu zemin kattaki ahır kısmı avluya bitişik olup, üst kat ise, yolcuların kalacakları üzeri tonozla örtülü odalar şeklinde inşa edilmiştir. Diktörgen şeklindeki avlunun ortasında bir havuz bulunmaktadır. Tuvaletler ve depolar da zemin kattadır. Kasabanın kâgir binalarında saklanan ziynet eşyaları meydana gelen yangınlarda zayi olduklarından han odalarında muhafaza edildiği kaydedilmektedir. ${ }^{89}$ Hanın ilk yapıldığında 65 odası bulunurken, sonradan odaların bölünmesiyle bu sayı 180 'e çıkarılmış ve şahıslara kiralanmıştır. ${ }^{90}$ Diğer taraftan iki katlı hanın abartılı bir şekilde üç yüzden fazla odası olduğu da belirtilmektedir. ${ }^{91}$ Zemin katında 26 oda ile iki mahzeni bir ahırı, üst katında 37 oda, bir mescidi ve ortasında bir şadırvan bulunmaktadır. ${ }^{92}$ Ahırın büyüklüğü $300 \mathrm{~m}^{2}$ avlu ise $250 \mathrm{~m}^{2}$ dir. ${ }^{93}$ Hana dışarıdan gelenlerin

84 Abdülkadir Özcan, "Safranbolu'da Üç Şahsiyet", 119-120; Selda Kalfazade, "Cinci Hanı", Türkiye Diyanet Vakfı İslâm Ansiklopedisi (İstanbul: Türkiye Diyanet Vakfı, 1993), 8/15.

85 Kâtip Çelebi, Cihannümâ, 1145, 653; Hulusi Yazıcıŏlu, Safranbolu Tarihine Ait Belgeler ve Kaynaklar, 43-44; Feridun Emecen, "Taraklıborlu'dan Safranbolu’ya, Bir Müze Şehr ve Yükselişi”, I. Ulusal Tarih İçinde Safranbolu Sempozyumu (4-6 Mayıs1999) (Ankara: Türk Tarih Kurumu, 2003), 20.

86 Ünal Özdemir - Güzin Kantürk Yiğit, “Değişen Fonksiyonel Özellikleri Açısından Safranbolu Cinci Hanı", Yükselen İpek Yolu, ed. Fahri Atasoy (Ankara: Türk Yurdu, 2016), 1/275.

87 Hulusi Yazıcıoğlu Hamide Hatun'un Cinci Hoca'nın annesi veya karısı olduğunu belirtiyorsa da arşiv belgelerinde annesi olduğu şüpheye yer bırakmayacak derecede açık olarak belirtilmektedir, bk. BOA, EV, d. 227, 780, 896, 502, 3756.

88 Hulusi Yazıcıŏglu, Safranbolu Tarihine Ait Belgeler ve Kaynaklar, 43; Aksoy, Kuş Aytekin, Müze Kent Safranbolu, 12.

89 Kalfazade, “Cinci Hanı”, 8/16.

90 Kalfazade, “Cinci Hanı”, 8/16.

91 Bir eserde hanın 62 odası olduğu belirtilmektedir, bk. Aksoy, Kuş Aytekin, Müze Kent Safranbolu, 12.

92 Abdulkerim Abdulkadiroğlu - Ülkü Özsoy, Safranbolu Vakfiyeleri (Ankara: Safranbolu Kültür ve Turizm Vakfı Yayınları, 1998), 18.

93 Özdemir - Yiğit, “Değişen Fonksiyonel Özellikleri Açısından Safranbolu Cinci Hanı”, 1/267.

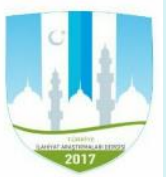

Türkiye İlahiyat Araştırmaları Dergisi

Turkey Journal of Theological Studies

ISSN: 2602-3067

[Tiad] 
görülebilmesi için ana kapının üzerinde çıkıntılı bir gözetleme kısım yer almaktadir..$^{94}$

17. yüzyılda İstanbul-Bolu-Amasya-Tokat-Sivas kervan yolunu Sinop'a bağlayan ticaret yolunun Gerede-Safranbolu-Kastamonu üzerinden geçmesi Safranbolu'nun önemli bir ticaret ve konaklama merkezi olmasında etkili olmuştur. Bu dönemde Cinci Hanı da konaklama için önemli bir işlev görmüştür. ${ }^{95}$ Tarihi süreç içinde ticaret yollarının değişmesiyle Cinci Hanı da işlevini yitirmiş, 19. yüzyıldan itibaren han odaları farklı kişilere kiralanarak bunlar tarafından depo ve değerli eşyaların muhafaza edildiği mekanlar olarak kullanılmaya başlanmıştır. Cinci Hanı her ne kadar orijinal özelliklerini kısmen kaybetmiş olsa da bugün hala ayakta olup, 2001 yılında yapılan restorasyon çalışmasından sonra 2004 yılından itibaren otel ve restoran olarak hizmet veren bir işletmeye dönüştürülmüştür. ${ }^{96}$

\subsection{Cinci Hamamı}

Safranbolu'da Cinci Hamamı (Yeni Hamam) adıyla bilinen hamam da han ile aynı tarihlerde bir vakıf eseri olarak yapılmıştır. ${ }^{97}$ Vakfiyeden ve arşiv kayıtlarından da handan başka bir de hamam olduğu açıkça anlaşılmaktadır. Hüseyin Efendi'nin annesi Hâmide Hatun vakfına ait olan hamam 1268/1852 senesinde 1.200, han ise 800, kuruşa kiralanmıştır. Vakfın o tarihteki mütevellilerinin de Hacı Abdullah Ağa, Feyzullah Ağa ve Ahmed Ağa olduğu kaydedilmektedir..$^{98}$

\subsection{Sarayları}

Cinci Hüseyin Efendi kazasker olduğu dönemde İstanbul'da 1054/1644-1645'te içinde yetmiş seksen semmur kürklü hizmetçinin bulunduğu büyük bir saray yaptırmıştır. Görenleri hayrete düşüren bu muhteşem sarayın yapımı için padişahın emriyle kendisine iki yüz yük akçe verilmiştir. ${ }^{99}$ Evliya Çelebinin Civan Kapıcıbaşı Mehmed Paşa Sarayının karşısında olduğunu belirttiği Cinci Hoca sarayının İstanbul'un en mükellef saraylarından olduğu anlaşılmaktadır.

94 Kalfazade, “Cinci Hanı”, 8/15; Aksoy, Kuş Aytekin, Müze Kent Safranbolu, 12; Dünden Bugüne Safranbolu, 90-91.

95 Muammer Aksoy-Aytekin Kuş, Müze Kent Safranbolu, 12.

96 Özdemir - Yiğit, “Değişen Fonksiyonel Özellikleri Açısından Safranbolu Cinci Hanı”, 1/267.

97 Aksoy, Kuş Aytekin, Müze Kent Safranbolu, 12; Ünsal Tunçözgür, Dünü ve Bugünü ile Safranbolu (Safranbolu: Işıl Yayınevi, 2002), 60.

98 BOA, Evkaf Defterleri [EV. d], No, 14874. 15 Ramazan 1268/3 Temmuz 1852.

99 Târîh-i Naîmâ, 3/1002-1003. Saray için şu beyit söylenmiştir: “Bina Emsilesin bilmezdi Cinci/Anın için başladı evvel binaya, bk. aynı yer.

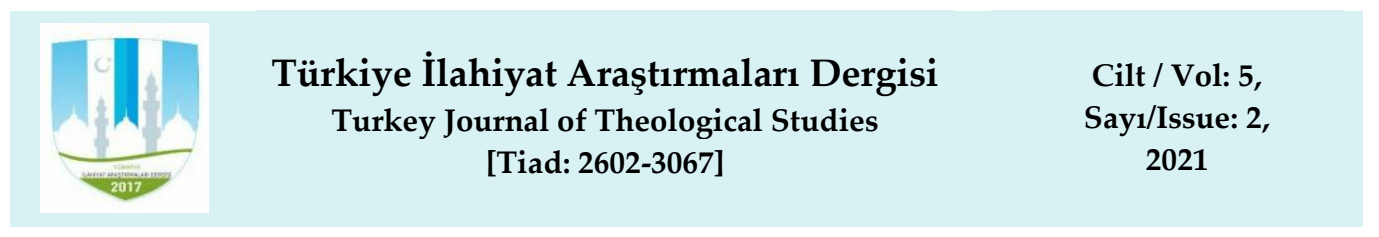


Hüseyin Efendi, Hâmid Efendi medresesinden arkadaşı olan Evliya Çelebi'yi sarayına davet ederek sohbet etmiş ve ona ikramlarda bulunmuştur. İki buçuk yıl öncesine kadar bu sarayın olmadığını belirten ve hayırlı olmasını dileyen Evliya Çelebi'ye, medrese köşesinde ilimle meşgul olduğundan Cenâb-1 Hak'kın ilmin bereketiyle bu sarayı lufettiğini, Üsküdar'da ve kendi memleketinde, daha başka yerlerde kendisine birçok çiftlikler ve çeşit çeşit nimetler ihsan ettiğini belirtmiştir. Arkadaşı Evliya Çelebi'ye gümüş eyerli Gazneli Sultan Mahmud'un fili gibi bir küheylan hediye etmiştir. Ayrıca evine şeker, kahve, bal, yağ gibi yiyecekler göndermiştir. ${ }^{100}$

Cinci Hüseyin Efendi'nin Safranbolu'da kâgir ve büyük bir sarayı olduğu, bu sarayın yerine hükûmet konağı inşa edildiği bildirilmiştir. ${ }^{101}$ Ancak Safranbolu eski hükûmet konağının Cinci Hoca'nın sarayına ait kalıntılar üzerinde olmayıp, Candaroğulları döneminde de idare merkezi olarak kullanılan ve kale denilen tepe üzerinde olduğu belirtilmektedir. Cinci Hoca'nın sarayının ise muhtemelen bugünkü Kalealtı İlkokulu'nun kuzeyinde duvarlarının yıkıntı halde bulunduğu ifade edilmektedir. ${ }^{102}$ Söz konusu han, hamam ve sarayı da kapsayan vakıf, Cinci Hoca'nın annesi Şeyh İshak Efendi'nin kızı Hâmide Hatun adına 1645 tarihinde tescil edilmiştir. Kendisi hayatta iken, vakfı annesinin adına tesis ettirmesinin kesin bir cevabı olmamakla birlikte, el konulmasına mâni olmak ihtimalini hatıra getirmektedir. ${ }^{103}$

\subsection{Diğer Eserleri}

Üsküdar İnâdiye'de Has Odalı Ahmet Ağa Sebilinin önünde vaktiyle Cinci Kuyusu olarak bilinen ve Meşhur Cinci Hüseyin Efendi tarafından açtırıldığı tahmin edilen, fakat bugün mevcut olmayan bir kuyu bulunmaktayd1. ${ }^{104}$ Cinci Hüseyin Efendi'nin kaynaklarda yeri belirtilmeyen Üsküdar'da bir de sarayından bahsedilmektedir. Yanında bir de hamamın bulunduğu ifade edilen bu sarayın 1645 yılında yapıldığı tahmin edilmektedir. Ancak Hüseyin Efendi'nin Üsküdar'da açtırdığı belirtilen kuyu ile yaptırdığı söylenen sarayı ve hamamının birbirine yakın yerlerde olması muhtemeldir. ${ }^{105}$

\section{Sonuç}

Safranbolulu Hüseyin Efendi, Osmanlı Tarihinde dikkat çekici bir sima olarak yer almıştır. Onu dikkat çekici sima haline getiren husus, efsunculuğu

\footnotetext{
100 Evliya Çelebi Seyahatnâmesi, 2. Kitap/247; Yüzyıllar Boyunca Üsküdar, 3/1340-1341.

101 Mehmed Behçet, Kastamonu Âsâr-ı Kadîmesi (Ankara: Maarif Vekâleti Hars Dairesi, 1341), 96; Tunçözgür Ünsal, Dünden Bugüne Safranbolu (Ankara: Safranbolu Hizmet Birliği Kültür Yayını, 1997), 90-91; Hulusi Yazıcıŏlu, Safranbolu Tarihine Ait Belgeler ve Kaynaklar, 43.

102 Hulusi Yazıcıoğlu, Safranbolu Tarihine Ait Belgeler ve Kaynaklar, 44.

103 Hulusi Yazıcıoğlu, Safranbolu Tarihine Ait Belgeler ve Kaynaklar, 4.

104 Haskan, Yüzyıllar Boyunca Üsküdar, 3/1213.

105 Haskan, Yüzyıllar Boyunca Üsküdar, -3/50, 964, 1213, 1340-1341.
}

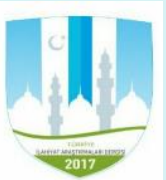

Türkiye İlahiyat Araştırmaları Dergisi 
sayesinde devlet nezdinde önemli mevkilere sahip olmasıdır. Memleketi Safranbolu'da sıradan bir kişi olan Hüseyin Efendi'nin medrese tahsili için İstanbul'a gitmesiyle hayatında yeni bir dönem başlamıştır. Burada bir taraftan medrese tahsiline devam ederken, bir taraftan da efsunculukla uğraşan Hüseyin Efendi'nin şöhretinin saraya kadar ulaşması üzerine hayatında yeni bir dönem başlamıştır. Şehzadeliği döneminde her an öldürüleceği korkusuyla yaşayan ve bu sebeple ruhi birtakım hastalıklara maruz kalan Sultan İbrahim, Hüseyin Efendi'nin uyguladığı tedavi yöntemleri ve okuduğu tesirli dualarla iyileşmiştir. Bundan sonra Hüseyin Efendi "Cinci" lakabıyla anılmaya başlamıştır. Böylece saraya intisap ederek Sultan İbrahim'in hocası makamına kadar yükseltmiştir

Medrese tahsilini bir tarafa bırakan Cinci Hüseyin Efendi, Sultan İbrahim nezdinde elde ettiği itibar sayesinde bazı pâyelere, birçok ikramlara ve ihsanlara mazhar olmuştur. Devletin en üst makamlarından biri olan kazaskerlik makamına kadar yükselmiştir. O dönemde Bolu sancağına bağlı bulunan Safranbolu ve civarında onlarca köy kendisine mülk olarak verilmiştir. Ancak ne ilmi ne devlet tecrübesi olan Cinci Hüseyin Efendi, bu hızlı yükselişi hazmedememiştir. Bulunduğu makamda bir devlet adamı ciddiyeti ortaya koyamamış, sahip olduğu makamı ve siyasi gücü, kendi menfaati doğrultusunda kullanmıştır. Sadrazam Kemankeş Kara Mustafa Paşa gibi önemli devlet ricalinin katledilmesinde etkili olmuş, rüşvetle iş görmeyi alışkanlık haline getirmiştir. Kısa zaman içinde çok büyük bir servetin sahibi olmuş ise de bu hızlı yükselişin ardından çok geçmeden başta elde ettiği makamı, serveti ve nihayet 1058/1648'de hayatını kaybetmiştir. Geriye Safranbolu'da annesi Hâmide Hatun adına kurduğu vakıf eserlerinden Cinci Hanı, Cinci Hamamı olarak bilinen bazı eserler kalmıştır. 


\section{Kaynakça / Reference}

Abdulkadiroğlu, Abdulkerim - Özsoy, Ülkü. Safranbolu Meşhurları. Ankara: Anıl Matbaa ve Ciltevi, 2000.

Abdulkadiroğlu, Abdulkerim - Özsoy, Ülkü. Safranbolu Vakfiyeleri. Ankara: Safranbolu Kültür ve Turizm Vakfı Yayınları, 1998.

Abdurrahman Abdi Paşa. Vekâyi nâme. İstanbul: Çamlıca Basım Yayın, 2008.

Ahmed Refik. Kadınlar Saltanatı. İstanbul: Orhaniye Matbaası, 1923.

Ahmed Refik. Semmur Devri. İstanbul: Marifet Matbaası, 1927.

Ahmed Reşid. Haritalı ve Resimli Mükemmel Tarih-i Osmanî. İstanbul: Artin Asaduryan ve Mahdumları Matbaası, 1327.

Ahmet Refik Altınay. Hoca Nüfûzu. İstanbul: Toplumsal Dönüşüm Yayınları, 1997.

Ahmet Refik Altınay. Tarihî Sîmalar Tesâvîr-i Ricâl. İstanbul: Tarih Vakfi Yurt Yayınları, 2011.

Aksoy, Muammer, Kuş Aytekin. Müze Kent Safranbolu. Ankara: Safranbolu Hizmet Birliği Kültür Yayını, 1996.

Altınay, Ahmet Refik. Tarihî Sîmalar Tesâvîr-i Ricâl. İstanbul: Tarih Vakfı Yurt Yayınları, 2011.

Barkan, Ömer Lütfi. Türkiye'de Toprak Meselesi Toplu Eserleri 1. İstanbul: Gözde Yayınları, 1980.

Bilkan, Ali Fuat. Fakihler ve Sofuların Kavgası. İstanbul: İletişim Yayınları, 2016.

Danışmend, İsmail Hâmi. İzahlı Osmanlı Tarih Kronolojisi. İstanbul: Türkiye Yayinevi, 1972.

BOA, Osmanlı Arşivi. Tapu Tahrir Defteri [TT. d]. No. 783.

BOA, Osmanlı Arşivi. Evkaf Defterleri [EV. d]. No. 14874.

BOA, Osmanlı Arşivi. Topkapı Sarayı Müzesi Arşivi Evrakı [TSMA. E]. No.794, Gömlek No. 29.

Deniz, Şefaattin. Safranbolulu İzzet Mehmed Paşa ve Dönemi. İstanbul: Bilge Kültür Sanat Yayını, 2016.

Emecen, Feridun. “İbrâhim”. Türkiye Diyanet Vakfı İslâm Ansiklopedisi. 21/274281. İstanbul: Türkiye Diyanet Vakfı, 2000.

Emecen, Feridun. “Tarakliborlu'dan Safranbolu'ya, Bir Müze Şehr ve Yükselişi". I. Ulusal Tarih İçinde Safranbolu Sempozyumu (4-6 Mayıs1999). Ankara: Türk Tarih Kurumu, 2003. 
Erkan, Davut. "Sofu Mehmed Paşa”. Türkiye Diyanet Vakfi İslâm Ansiklopedisi. Ek-2/515-517. İstanbul: Diyanet Vakf1, 2016.

Evliya Çelebi. Evliya Çelebi Seyahatnâmesi. İstanbul: Yapı Kredi Yayınları, 1996.

Evliya Çelebi. Evliya Çelebi Seyahatnâmesi. İstanbul: Yapı Kredi Yayınları, 1999.

Finkel, Caroline. Rüyadan İmparatorluğa Osmanlı İmparatorluğu'nun Öyküsü 1300-1923. çev. Zülal Kılıç. İstanbul: Timaş Yayınları, 2007.

Gökbilgin, Tayyip. “İbrahim”. İslam Ansiklopedisi. C. 5. Ankara: Milli Eğitim Basımevi, 1967.

Göktürk, Hakkı. "Cinci Akçesi, Cinci Parası”. İstanbul Ansiklopedisi. ed. Reşad Ekrem Koçu. C. 7. İstanbul: İstanbul Ansiklopedisi ve Neşriyat, 1965.

Güngör, Fatma Nur. Cinci Hoca (Hüseyin Efendi)'nin Safranbolu'daki Hayratı: Hamide Hatun Vakfı. Karabük: Karabük Üniversitesi, Yüksek Lisans, 2014.

Haskan, Mehmet Nermi. Yüzyıllar Boyunca Üsküdar. İstanbul: Üsküdar Belediyesi, 2001.

İpşirli, Mehmet. “Temliknâme”. Türkiye Diyanet Vakfı İslâm Ansiklopedisi. 40/430431. Ankara: Türkiye Diyanet Vakfı, 2011.

İşbilir, Ömer. "Mekkâre". Türkiye Diyanet Vakfı İslâm Ansiklopedisi. 28/554-555. Ankara: Türkiye Diyanet Vakfı, 2003.

İşbilir, Ömer. “Nüzül”. Türkiye Diyanet Vakfı İslâm Ansiklopedisi. 33/311-312. İstanbul: Türkiye Diyanet Vakfı, 2007.

Johann Wilhelm Zinkeisen. Osmanlı Imparatorluğu Tarihi. çev. Nilüfer Epçeli. İstanbul: Yeditepe Yayınevi, 2011.

Joseph Freiherr von Hammer Purgstall. Büyük Osmanlı Tarihi. çev. Mümin Çevik - Erol Kılıç. İstanbul: Üçdal Neşriyat, 1990.

Kalfazade, Selda. "Cinci Hanı". Türkiye Diyanet Vakfı İslâm Ansiklopedisi. 8/1516. İstanbul: Türkiye Diyanet Vakfı, 1993.

Kallek, Cengiz. "Müd". Türkiye Diyanet Vakfı İslâm Ansiklopedisi. 31/457-459. İstanbul: Türkiye Diyanet Vakfı, 2006.

Kâmil Paşa. Târih-i Siyâsi Devlet-i Aliyye-i Osmâniyye. İstanbul: Ahmed İhsan Matbaası, 1327.

Kara Çelebi-zâde Abdülaziz Efendi. Ravzatü'l-Ebrâr Zeyli (Tahlîl ve Metin). Ankara: Türk Tarih Kurumu, 2003. 
Katg1, İsmail. “Osmanlı Devleti'nde Ulemâ Yozlaşmasının Tipik Bir Temsilcisi Olarak Safranbolu'lu Hüseyin Efendi: Nam-1 Diğer Cinci Hoca”. Hikmet Yurdu 5/10 (Aralık 2012), 197-235.

Kâtib Çelebi. Fezleke. İstanbul: Çamlıca Basım Yayın, 2016.

Kâtip Çelebi. Cihannümâ, 1145.

Kâtip Çelebi. Fezleke. İstanbul: Ceride-i Havadis Matbaası, 1287.

Mantran, Robert. 17. Yüzyılın İkinci Yarısında İstanbul. çev. M. Ali Kılıçbay, Enver Özcan. Ankara: Türk Tarih Kurumu, 1990.

Mehmed Behçet. Kastamonu Âsâr-ı Kadîmesi. Ankara: Maarif Vekâleti Hars Dairesi, 1341.

Mehmed Halife. Târih-i Gılmânî. Ankara: Kültür ve Turizm Bakanlığı Yayınları, 1986.

Mehmed Süreyya. Sicill-i Osmânî. İstanbul: Sebil Yayınevi, 1996.

Muhibbî. Hülâsatü'l-Eser. Beyrut, Tarihsiz.

Mustafa Nuri Paşa. Netâyicü'l-Vukū'ât. Ankara: Birleşik Yayınevi, 2008.

Naima Mustafa Efendi. Tarih-i Naîma. Ankara: Türk Tarih Kurumu, 2007.

Özcan, Abdülkadir. "Hüseyin Efendi, Cinci Hoca”. Türkiye Diyanet Vakfı İslam Ansiklopedisi. 18/541-543. İstanbul: Türkiye Diyanet Vakfı, 1998.

Özcan, Abdülkadir. "Safranbolu'da Üç Şahsiyet". I. Ulusal Tarih İçinde Safranbolu Sempozyumu (4-6 Mayıs1999). Ankara: Türk Tarih Kurumu, 2003.

Özdemir, Ünal - Yiğit, Güzin Kantürk. “Değişen Fonksiyonel Özellikleri Açısından Safranbolu Cinci Hanı". Yükselen İpek Yolu. ed. Fahri Atasoy. Ankara: Türk Yurdu, 2016.

Sertoğlu, Midhat. Osmanlı Tarih Lîgatı. İstanbul: Enderun Yayınları, 1986.

Solakzâde Mehmed Hemdemî Çelebi. Solak-zâde Tarihi. Ankara: Kültür Bakanlığı Yayınları, 1989.

Şem‘dânizâde Fındıklı Süleyman Efendi. Müri’t-Tevârrîh (180B-345A). İstanbul: İstanbul Üniversitesi, Yüksek Lisans, 2009.

Şemseddin Sami. Kâmusu'l-A ‘lâm. İstanbul: Mihran Matbaası, 1308.

Şeyhi Mehmed Efendi. Şekāik-ı Numaniye ve Zeyilleri Vekâyiu'l-Fudalâ,. İstanbul: Çağrı Yayınları, 1989.

Tabakoğlu, Ahmet. “Tekâlif”. Türkiye Diyanet Vakfı İslam Ansiklopedisi. 40/336337. İstanbul: Türkiye Diyanet Vakfı, 2011.

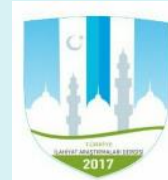

Türkiye İlahiyat Araştırmaları Dergisi 
Tan, M. Turhan. Osmanlı Rasputini Cinci Hoca. İstanbul: İnk1lap ve Aka Kitabevleri, Tarihsiz.

Tektaş, Nazım. Osmanlı 2 (Saraydan Sürgüne). İstanbul: Burak Yayınları, 1999.

Tunçözgür, Ünsal. Dünden Bugüne Safranbolu. Ankara: Safranbolu Hizmet Birliği Kültür Yayını, 1997.

Tunçözgür, Ünsal. Dünü ve Bugünü ile Safranbolu. Safranbolu: Işıl Yayınevi, 2002.

Uzunçarşılı, İsmail Hakkı. Osmanlı Tarihi. Ankara: Türk Tarih Kurumu, 1988.

Ünal, Tahsin. “Cinci Hoca ve Serveti Hakkında”. Resimli Tarih Mecmuası.

Ünlü, Seyfettin. "Yeniçeriler". Osmanl Ansiklopedisi. C. 4. İstanbul: Ağaç Yayıncilik, 1997.

Yazıcıoğlu, Hulusi. Küçük Osmanlı'nın Öyküsü Safranbolu. İstanbul: Şa-to Türkiyat, 2001.

Yazıcıoğlu, Hulusi. Safranbolu Tarihine Ait Belgeler ve Kaynaklar. Ankara: Safranbolu Hizmet Birliği Kültür Yayınları, 1998.

Ziya Şakir. “Osmanlı Tarihinin Rasputini Cinci Hoca Hüseyin Efendi”. Resimli Tarih Mecmuası 2/24 (Aralık 1951), 1178. 